\title{
Post-Accident Cleanup of Radioactivity at the Three Mile Island Nuclear Power Station
}

R. E. Brooksbank

W. J. Armento

OPERATED BY

UNION CARBIDE CORPORATION FOR THE UNITED STATES DEPARTMENT OF ENERGY 


\section{DISCLAIMER}

This report was prepared as an account of work sponsored by an agency of the United States Government. Neither the United States Government nor any agency Thereof, nor any of their employees, makes any warranty, express or implied, or assumes any legal liability or responsibility for the accuracy, completeness, or usefulness of any information, apparatus, product, or process disclosed, or represents that its use would not infringe privately owned rights. Reference herein to any specific commercial product, process, or service by trade name, trademark, manufacturer, or otherwise does not necessarily constitute or imply its endorsement, recommendation, or favoring by the United States Government or any agency thereof. The views and opinions of authors expressed herein do not necessarily state or reflect those of the United States Government or any agency thereof. 


\section{DISCLAIMER}

Portions of this document may be illegible in electronic image products. Images are produced from the best available original document. 


\section{Printed in the United States of America. Available from National Technical Information Service \\ U.S. Department of Commerce \\ 5285 Port Royal Road, Springfield, Virginia 22161 \\ NTIS price codes-Printed Copy: A04 Microfiche A01}

This report was prepared as an account of work sponsored by an agency of the United States Government. Neither the United States nor any agency thereof, nor any of their employees, makes any warranty, expressed or implied, or assumes any legal liability or responsibility for any third party's use or the results of such use of any information, apparatus, product or process disclosed in this report, or represents that its use by such third party would not infringe privately owned rights. 
Contract No. W-7405-eng-26

CHEMICAL TECHNOLOGY DIVISION

\title{
POST-ACCIDENT CLEANUP OF RADIOACTIVITY AT THE \\ THREE MILE ISLAND NUCLEAR POWER STATION
}

Compi ied by:

R. E. Brooksbank

W. J. Armento

\section{Contributors:}

D. 0. Campbel1

E. D. Collins

F. E. Harrington

L. J. King

J. R. Parrott, Sr.

W. A. Shannon

J. W. Snider

\section{Dale Published: February 1980}

NOTICE This document contains information of a preliminary nature. It is subject to revision or correction and therefore does not represent a final report.

\author{
OAK RIDGE NATIONAL LABORATORY \\ Cak Ridge, Tennessee 37830 \\ operated by \\ UNION CARBIDE CORPORATION \\ for the \\ DEPARTMENT OF ENERGY
}




\section{THIS PAGE}

\section{WAS INTENTIONALLY LEFT BLANK}


ABSTRACT

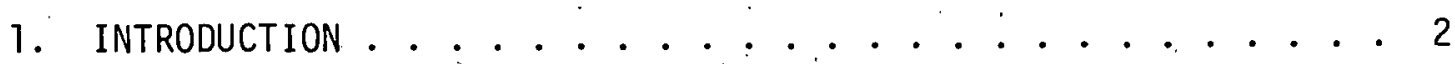

2. CONTAMINATED AIR HANDLING $\ldots \ldots \ldots \ldots \ldots$

2.1 Status of the Off-Gas System Following the Accident . . . 3

2.2 Modifications to the Off-Gas System ......... 4

2.3 Results ................. 4

3. CONTAMINATED WATER TREATMENT . . . . . . . . . 8

3.1 Status of TMI Water Following the Accident . . . . 8

3.2 Treatment of Low-Activity-Level Water ........ 11

3.3 Treatment of Intermediate-Activity-Level Wáter . . . 13

3.3.1 Quantity and characteristics........ 13

3.3.2 Processing justification .......... 13

3.3.3 Process description ......... 15

3.3.4 Process environmental assessment . . . . . . . 17

3.4 Treatment of High-Activity-Level Water . . ..... 18

3.4.1 Quantity and characteristics ......... 18

3.4 .2 Necessity for emergency tankage ........ . 18

3.4 .3 Processing justification ........... 21

3.4.4 Flowsheet development ..........23

3.4.5 Process design objectives and criteria..... . 23

3.4.6 System and process description........ 29

4. RADIOACTIVE SOLID WASTE HANDLING ............... 38

4.1 Quantities and Characteristics ......... 38

4.2 Solid Waste Shipments and Container Information.... 39

4.2.1 Transportation equipment availability for shipment.................... 39

4.3 Solid Waste Storage Facility Installation . . . . . 4 4

4.3.1 Interim solid waste staging facility...... 41

4.3.2 Solid waste staging facility .......... 41

5. FACILITY DECONTAMINATION . . . . . . . . . . . 42

5.1 Diesel Generator Building . . . . . . . . . 42

5.2 Auxiliary Building and Fuel Handling Building...... 43

5.3 Containment Facility Recommissioning ....... 45 
5.3.1 Status of containment and components ...... . 45

5.3.2 Major construction, services, and equipment requirements for decontamination. . . . . . . 46

5.3.3 Containment reentry and decontamination . . . . 48

5.3.4 Reactor coolant system cleanup . . . . . . . . 53

5.3.5 Reconstruction and recommissioning . . . . . . . 53

5.3.6. Wastes generated from decontamination . . . . 54

5.4 Costs and Schedules............... . . . 54

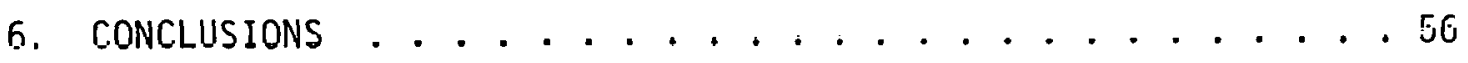

6.1 Contaminated Air . . ................ 56

6.? Contaminated Water ................ . 56

6.2.1 Low-activity-level water ............ . 56

6.2 .2 Intermediate-activity-level water . . . . . . 56

6.2.3 High-activity-level water . . . . . . . . 56

6.3 Radioactive Solid Waste . . . . . . . . . . . 57

6.4 Facility Decontamination ................. . . 57

6.5 Recommissioning . . . . . . . . . . . . . 58

7. REFERENCES ........................ 59 
Compiled by:

R. E. Brooksbank

W. J. Armento

\section{ABSTRACT}

The technical staff of the President's Commission on the Accident at Three Mile Island (TMI) requested that oak Ridge National Laboratory (ORNL) prepare documentation concerned with the cleanup of radioactivity on the Three Mile Island site following the March 28, 1979 accident. This report is a compilation of data generated by ORNL staff members, and it represents the status of the site as of September 7, 1979.

The objective of this report is to provide information in a summarized form, which will be of dirert. usefulness to the commissioners. The information contained herein includes discussion of on-site assistance and accomplishments following the accident, flowsheet development for the TMI recovery team (by the Technical Advisory Group), and the numerous reports already generated on the TMI cleanup and recovery. 


\section{INTRODUCTION}

This document contains information specifically requested by the technical staff of the President's Commission on the Accident at Three Mile Island (TMI). Oak Ridge National Laboratory (ORNL) was instructed to generate documents concerned with two areas: instrumentation diagnostics and the treatment of radioactive wastes and liquid effluents stemming from the accident. This report responds to the latter category.

The three primary concerns to be addressed in this repnrt. are:

1. The distribution of radioactivity in the air and watcr following the accident, iodine and xenon being of primary interest:

2. The decontamination and immobilization of radionuclides from the radioactive air and water contained with in TMI.

3. The treatment of gaseous, liquid, and solid wastes at TMI. These concerns are discussed in Sects. 2, 3, and 4, respectively, As the result of the accident at the Three Mile Island Nuclear Power Station, Unit 2 Reactor (TMI-2), radioactivity was found in or on several materials external to the reactor itself. Radioactive contamination levels were established in the off-gases, water, and on the surfaces of affected facilities and miscellaneous materials. In order to address the problems and status of the cleanup operations necessary to restore the site to its normal condition, this report has been divided into four major sections: (1) contaminated air handling, (2) contaminated water handling, (3) solids handling, and (4) facility decontamination. Because limited information exists on the exact condition of the reactor containment structure, the last section addresses the problems inherent in recommissioning the reactor based on a recent. study ${ }^{1}$ conducted hy Bechtel.

Members of the ORNL. staff continue to provide assistance that is requested. The areas of waste management in which ORNL remains active are analytical chemistry support and flowsheet development for treatment of radioactive water. The development of suitable flowsheets for the decontamination and disposal of high-activity-level water, which is an integral part of TMI's present recovery effort, has been briefly covered in this report as a means of providing continuity to the input of information to the Commission. Also, R. E. Brooksbank serves as a member of the Technical Advisory Group (TAG) to the Waste Management Group (WMG) at TMI. 


\section{CONTAMINATED AIR HANDLING}

The total release of radioactivity to the environment throughout the accident period has been established as 13 to $16 \mathrm{Ci}$ of iodine $\mathrm{C}^{2-5}$ and 2.4 million to 13 million $C i$ of noble gases. ${ }^{3-6, *}$ The air pathway for release of this radioactivity was from the fuel to the primary coolant, which later carried some of it to the water outside the primary loop. This radioactivity was then volatilized from this water into the gaseous atmosphere in contact with the water (Containment Building, Auxiliary Building, and certain tanks) and finally vented, along with the other gases, to the plant off-gas treatment trains. Under the conditions of the accident, nearly all of the iodine would be expected to be dissolved in, and to be carried with, the primary coolant. A very small fraction of the iodine would volatilize into the gas phases above these liquids; in contrast, a large fraction of the xenon would be present in the gas volumes. Within the off-gas trains, charcoal trapping of the isotopes of jodine usually is effective for removal; however, no protection is afforded in the trains for noble-gas removal.

\subsection{Status of the Off-Gas System Following the Accident}

An assessment of the conditions of the off-gas handling and treatment system for the reactor and support buildings began shortly after the accident and is still in progress. The immediate problem following the accident was release of iodine and noble gases in excess of release specifications for normal operations. Because lodine has a more pronounced effect on the health and welfare of the downstream population, serious attention was given to the effectiveness of the charcoal traps designed to remove this isotope. Both downstream and upstream samples of the charcoal traps contained in the Auxiliary 2 and Fuel Handling Buildings, through which all gaseous releases from TMI-2 emanated, indicated that the traps were ineffective 2,4 for removal of iodine. Problems inherent in establishing the effectiveness of the off-gas removal systems

*The bulk of the environmental release of TMI-2 accident-evolved radioactivity. was restricted to the air pathway. An additional estimated $0.24 \mathrm{Ci}$ of $131 \mathrm{I}$ was released to the Susquehanna River between March 28 and April 30, 1979. (Data is based on a GPU assessment of off-site doses--see Pick and Lowe and Gorrick, Draft Assessment of Off-Site Doses, TDR-TMI-116, JuTy 31, 1979). 
involved the high radiation levels surrounding both the monitoring equipment and the traps themselves. Figure 1 shows a schematic representation of the off-gas system immediately following the accident.

\subsection{Modifications to the Off-Gas System}

Results of the tests conducted on the iodine trapping efficiency of the charcoal units within the Auxiliary 2 and Fuel Handling Buildings indicated that all the traps should be replaced. Therefore, a total of 300 traps were changed (180 in the Auxiliary Building and 120 in the Fuel Handling Building) throughout the period April 20 to May 3.

Because the reactor system was not yet stabilized from the standpoint of the natural convection cooling mode and the primary loop contained an estimated 6 million $\mathrm{Ci}$ of iodine, the decision was made to provide the existing off-gas trains with a supplemental system. This system, which contained four trains totaling a treatment capacity of 100,000 cfm, was located in Pasco, Washington. It was flown to the TMI-2 site for installation on the Auxiliary 2 Building roof and was placed onstream on May 3, 1979. Currently, three of the four trains are in operation. ${ }^{3}$ Figure 2 summarizes, in schematic fashion, the overall modifications made to the off-gas system. An additional modification, shown on the figure, is the capping of the stack vent; this provided an added margin of safety.

In addition to the modifications outlined, the floor areas suspected to be contaminated by iodine-containing solution were frequently wet with sodium thiosulfate in an attempt to decrease the level of iodine activity in the Auxiliary Building atmosphere (and thus reduce the iodine release).

\subsection{Results}

The actions discussed above, along with a major effort to minimize transfer and/or leakage of solutions containing iodine and noble gases, led to a steady decrease in iodine release (Fig. 3 ). The most significant reductions were achieved when the existing charcoal adsorbers were changed, when the new charcoal treatment system became operative, and when the plant stack was capped. The level of ${ }^{131}$ I release varied from 0.05 to $2 \mathrm{Ci} /$ day, which exceeded the technical specification quarterly average release rate 7 imit of $0.002 \mathrm{Ci} /$ day. ${ }^{4}$ When the new set of, adsorbers was put into operation on May 3 , the ${ }^{131}$ I release rate dropped to approximately $1 \mu \mathrm{Ci} /$ day. 


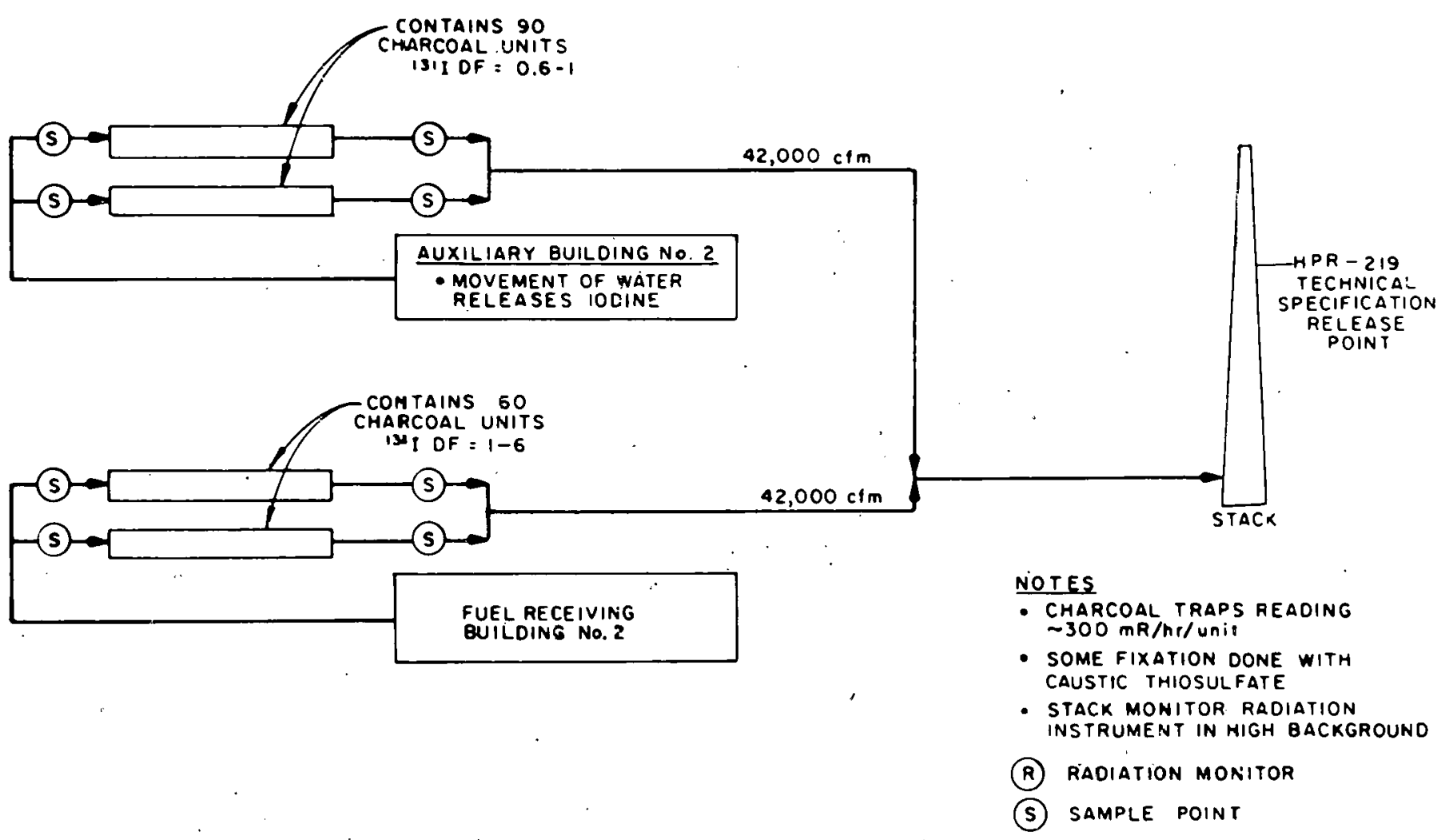

Fïg. 1. Off-gas system following accident. 


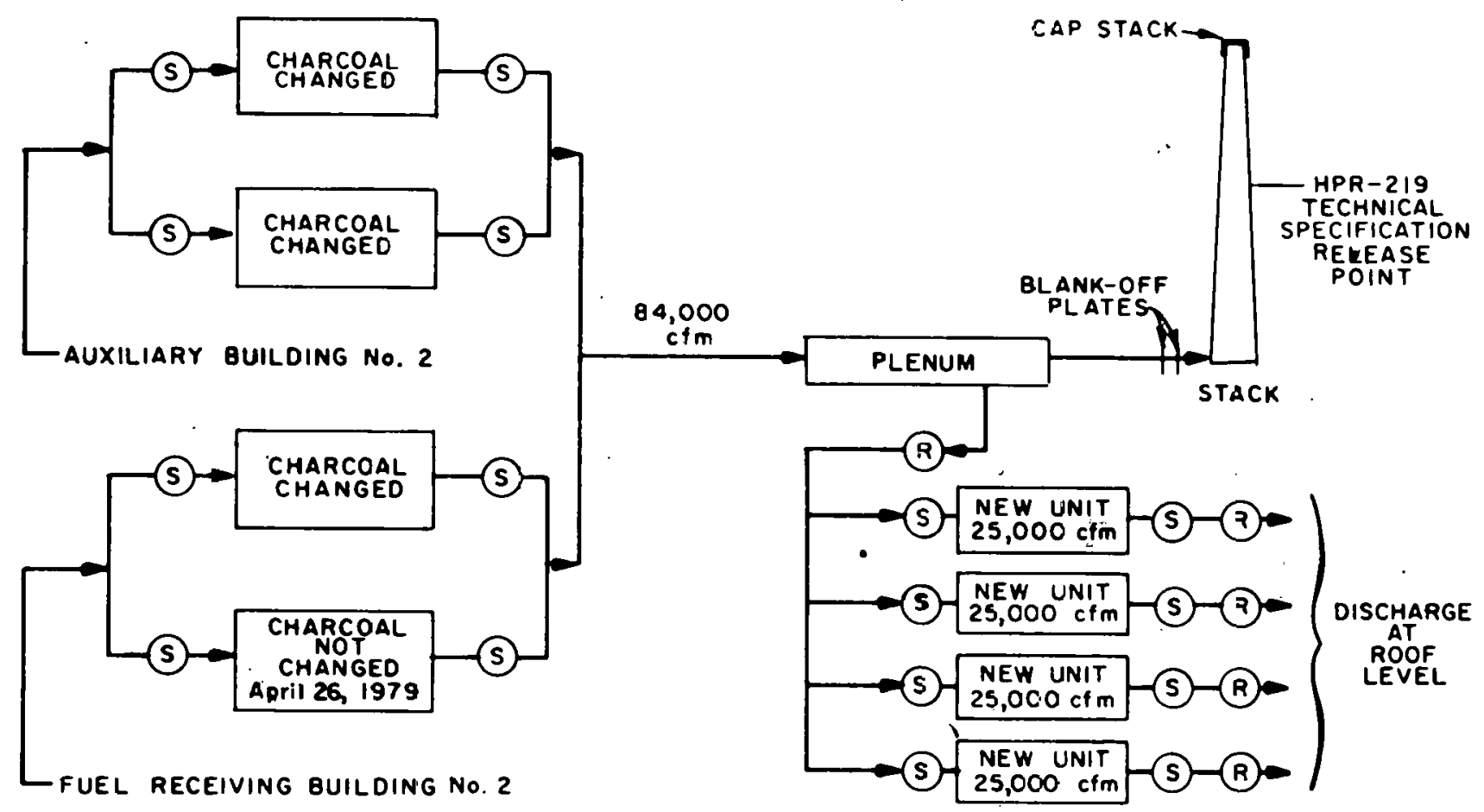

(8) RADLATION MONITOR

(S) SAMPLE POINT

Fig. 2. Cff-gas system modifications. 
ORNL DWg 79-13231A

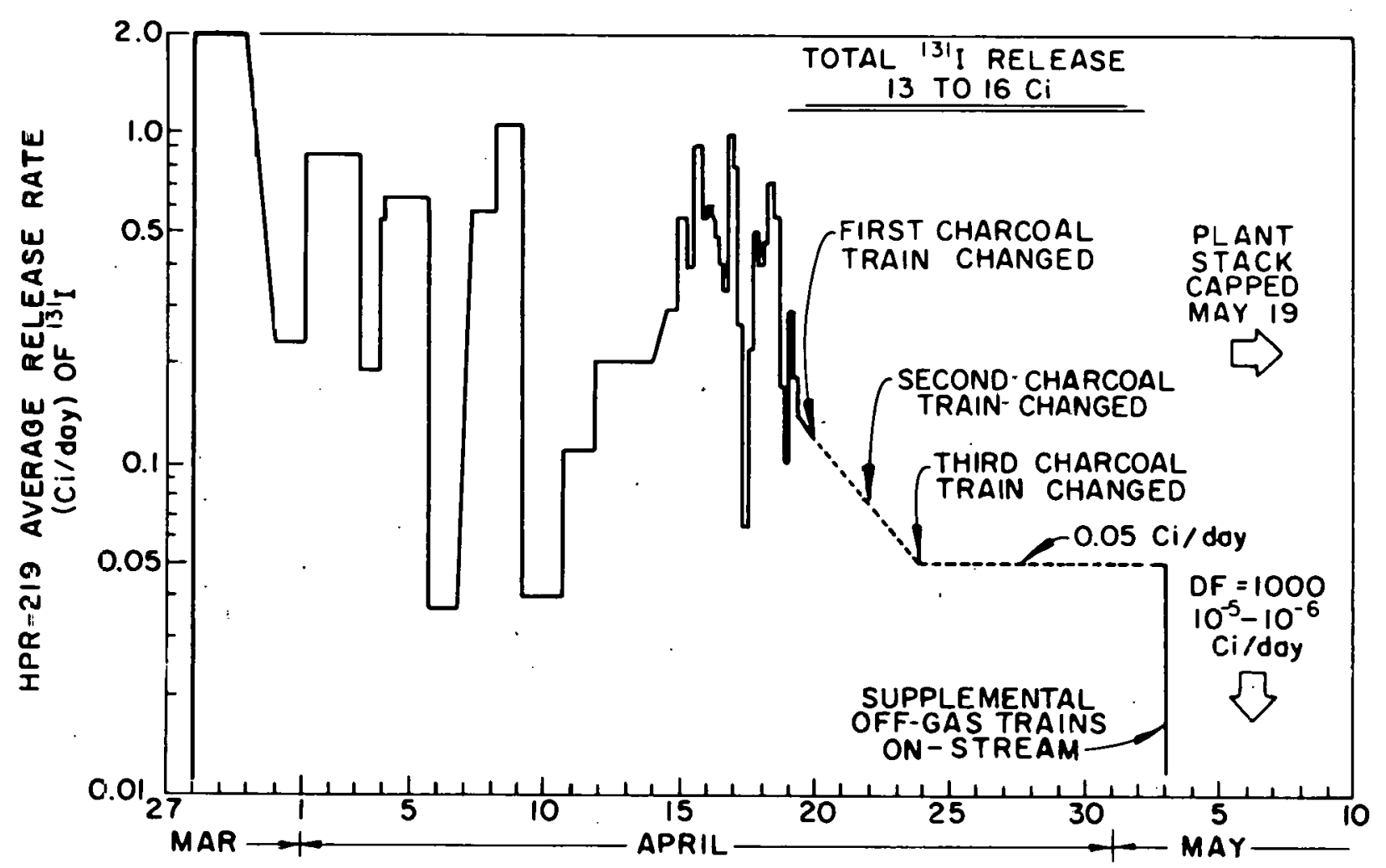

Fig. 3. ${ }^{137}$ Iodine release data. 


\section{CONTAMINATED WATER TREATMENT}

Contaminated water was continually being generated at TMI following the accident because of leakage through pump seals, flushing of sampling systems, and flushing of contaminated floor areas. The major concern relative to this water was that the quantity to be accumulated might exceed the storage capacity. There was also concern that the water level in the Containment Building might rise high enough to render inoperative some vital instruments. The eventual need to treat all of the liquids, including the primary coolant and all decontamination solutions, was considered throughout the planning for water handling.

\subsection{Status of TMI Water Following the Accident}

The status of the liquid handling systems as of April 1, 1979, 2 is shown in Fig. 4; the locations of pertinent areas are designated in Fig. 5. The primary reactor coolant loop contained 87,000 gal of highly radioactive coolant with an Iodine-131 inventory of about $6,000,000 \mathrm{Ci}$. In addition, the Reactor Containment Building was estimated to contain about 225,000 gal of water which had been contaminated by a large volume of the radioactive reactor coolant. Some instruments were inoperative, probably because they were submerged. The tanks in the Unit 2 Auxiliary Building were becoming full, and floor areas had become flooded with water that had overflowed or leaked from the tanks. Portions of this water were contaminated to varying degrees by water that had been transferred from the Containment Building sump before the Containment Building had been isolated, and subsequently had been transferred within the Auxiliary Building system during post-accident operations. The Unit 2 Reactor Building went into containment approximately $4 \mathrm{hr}$ after the accident and has remained in this state ever since.

The Unit 1 Reactor, which had been shut down for refueling prior to . the accident, was being brought up to operating temperature by the reactor coolant pump energy input prior to going critical. The available tankage within the Unit 1 Auxiliary Building was becoming filied with water due to normal leaks from Unit 1 water (very little TMI-2 post-accident water entered the Unit 1 Auxilịary Building). 
TMI UNIT 2

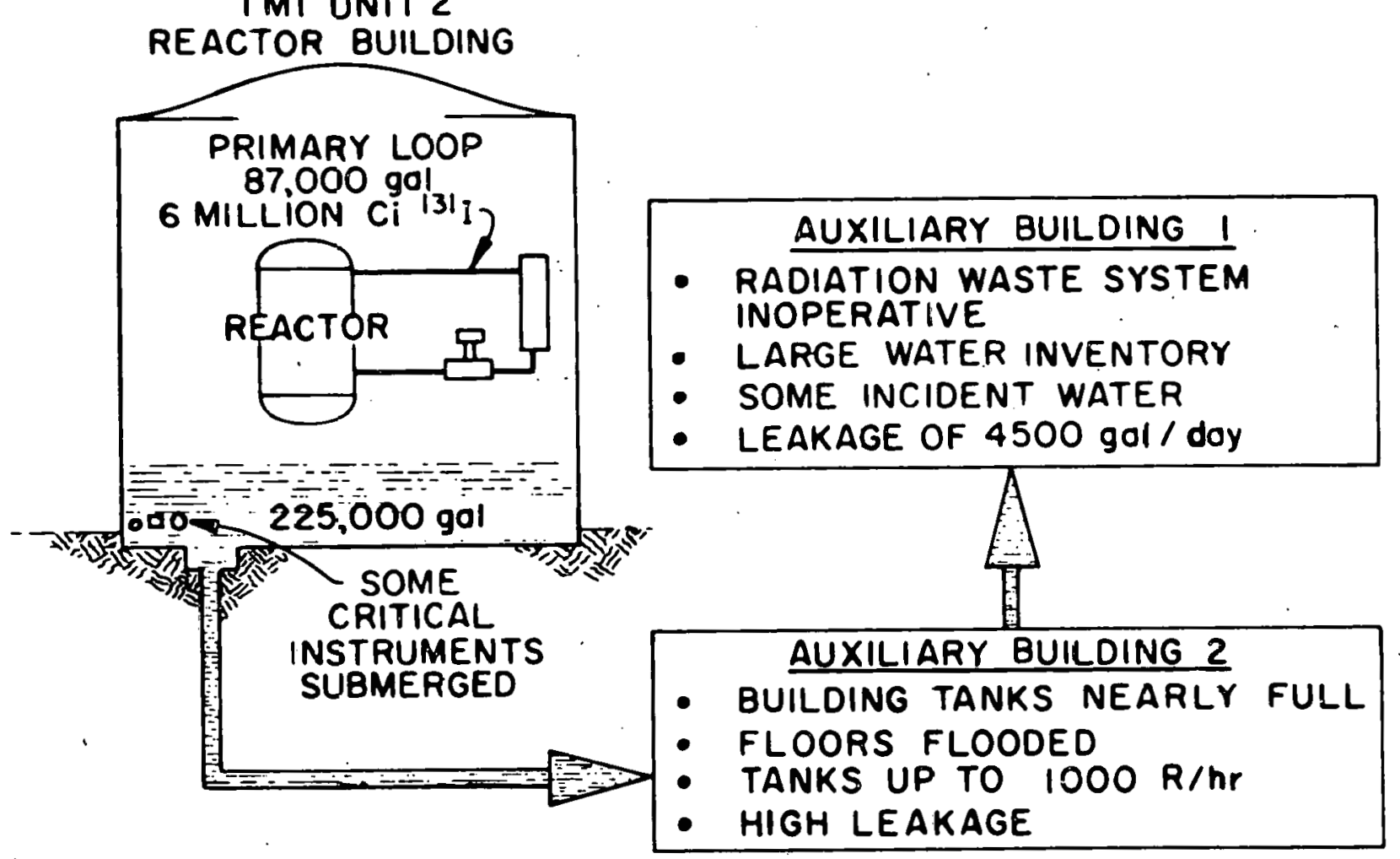

Fig. 4. Status of liquid at TMI after accident. 


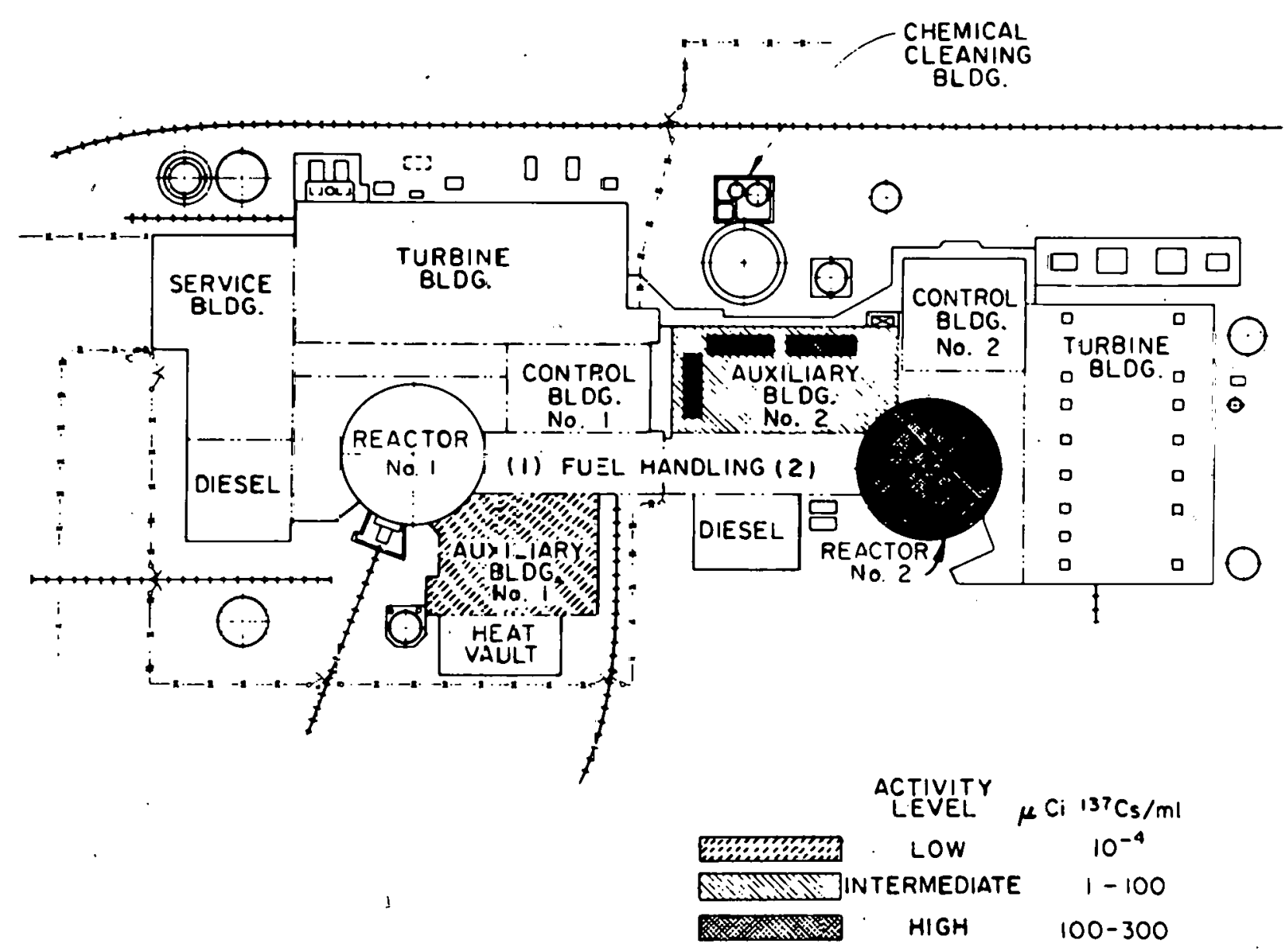

Fic. 5. Distribution of contaminated iquid. 
None of the Unit 2 water could be treated. The Unit 2 reactor coolant letdown stream could not be treated because of mechanical problems in the Unit 2 reactor coolant letdown evaporator. Earlier, the other liquid. wastes originating in Unit 2 were normally treated in the Unit 1 miscellaneous waste evaporator, which was out of service because a demineralizer bed was being changed. In any case, the transfer of Unit 2 post-event water to the Unit 1 Auxiliary Building was considered to be undesirable, and only a minor amount of TMI-2 post-accident water was transferred to Unit 1 systems.

Water inventories in both the Auxiliary Buildings were increasing. There was an urgent need for additional storage and/or water treatment facilities.

\subsection{Treatment of Low-Activity-Level Water}

Low-activity-level water (LALW) was originally defined as all water from Unit 1 and any pre-event water, as confirmed by analysis, in Unit 2. However, when analysis of the Unit 2 water revealed that some Unit 2 postevent water had inadvertently been transferred into the Unit 1 Auxiliary Building vessels, the definition of LALW was modified to include any water that had an ${ }^{131} \mathrm{I}$ activity of less than $0.1 \mu \mathrm{Ci} / \mathrm{ml}$ and contained no actinides.

A deininerdicer system (F1g. 6 ) consisting of a filter followed by a mixed-bed demineralizer for activity removal was set up on the west side of the Unit 1 Fuel Handling Building to process Unit 1 LALW. This system was referred to as Epicor-1 (initially Cap-Gun-1) because it was being operated by Capolupo \& Gundal. Inc. Two 20,000-gal Haliburton tanks were available for the decontamination water. The first-pass decontaminated water went into one Haliburton tank and was sampled. If the water had not been decontaminated sufficiently to permit release in one treatment cycle, the filter and mixed demineralizer beds were changed and a second decontamination run was inade. The second-pass decontaminated water was routed to the second 20,000-gal Haliburton tank.

The first batch of water treated by this system required two passes to meet the technical specifications for release to the Susquehanna River. All subsequent batches required two cycles of treatment. The first batch of water that was successfully treated was released to the Susquehanna River beginning on the night of April 11, 1979. By June 6, a total of 103,500 gal of water had been treated and released to the river. 


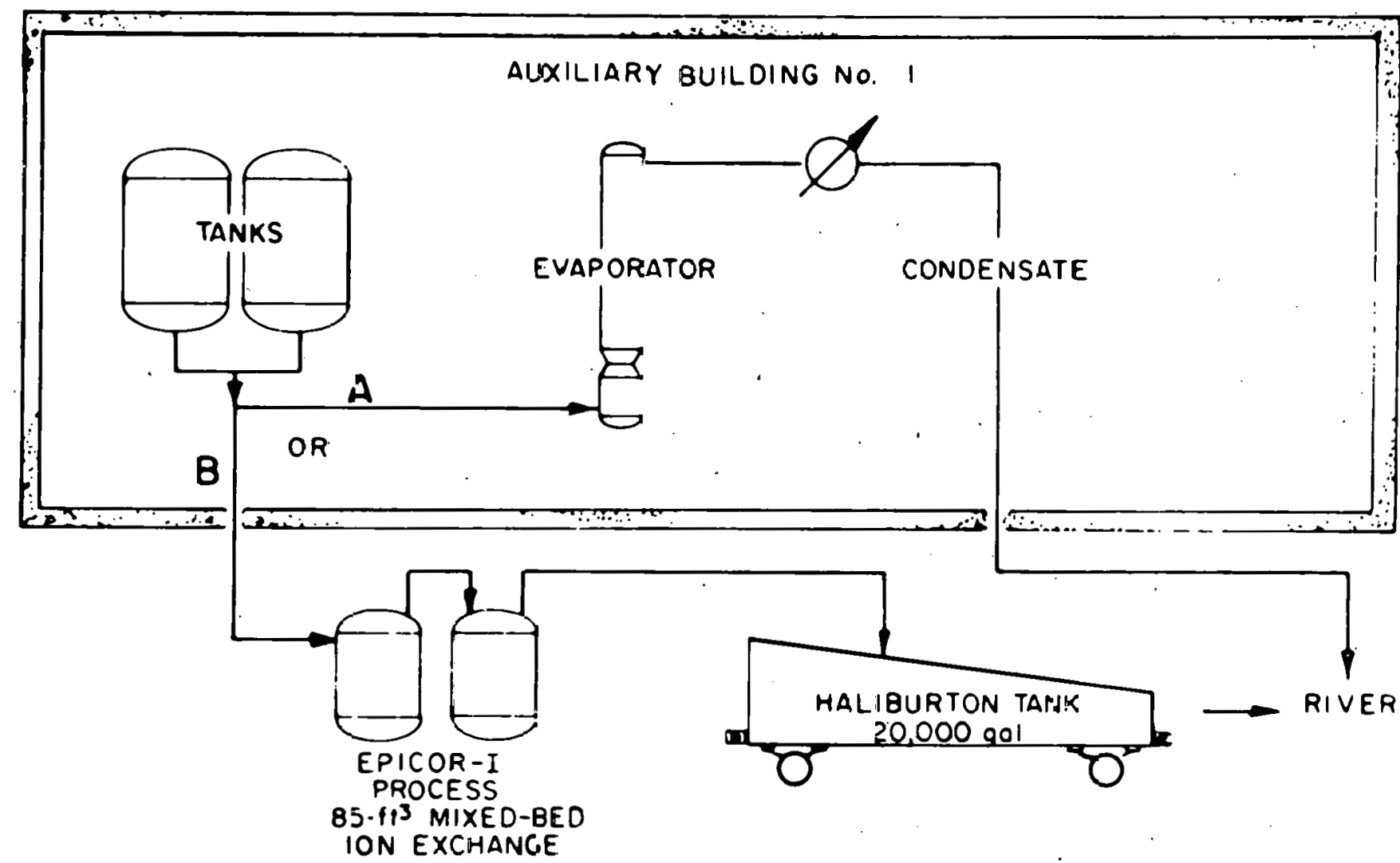

Fig. 6. Epicor-I (Cap-Gun-1) demineralizer systerr. 


\subsection{Treatment of Intermediate-Activity-Level Water}

As the result of the accident, a significant quantity of radioactive water was generated and collected in the Unit 2 Auxiliary Building tankage. For the most part, this solution can be characterized as intermediate-activity-level water (IALW), which can be defined as water containing ${ }^{131} \mathrm{I}$ and ${ }^{137} \mathrm{Cs}$ at concentrations greater than $\mathrm{I} \mu \mathrm{Ci} / \mathrm{ml}$ but less than $100 \mu \mathrm{Ci} / \mathrm{ml}$.

\subsubsection{Quantity and characteristics}

The wastewater in this category was produced from the following four sources: (1) an inventory of wastewater $(130,000 \mathrm{gal})$ that existed in the Unit 2 Auxiliary Building tankage prior to the accident; (2) contaminated water from the Reactor Containment Building sump that had been transferred to the Auxiliary Building and collected in various tanks (4200 gal) during the early phases of the accident; (3) letdown water from the reactor coolant system, which resulted in a net increase in the inventory; and (4) normal leakage from system components in the Auxiliary Building.

As can be seen from Table 1, the total volume contained in the Auxiliary Building tankage is approximatcly 279,000 gal: Table 1 also gives the concentrations of the principal radionuclides present in the various solutions contained in the tanks.

\subsubsection{Processing justification}

Although the Auxiliary Building is of sufficiently high integrity that contaminated water can be positively controlled for an indefinite period, there are several significant reasons why the decontamination of this water is beneficial. Most importantly, the radioactivity in the water stored in the Auxiliary Building must be potentially mobile. The contaminated water is presently secure, but it represents greater vulnerability to release in its present form. Additionally, the wastewater in the Auxiliary Building continues to be a source of exposure to personnel needing entry into the Auxiliary Building. The continued safe shutdown of TMI-2 depends on the operability of original plant equipment located in the Auxiliary Building and the use of additional equipment 
Tasle 1. Volumes of solution and concentrations of principal nuclides in Auxiliary Building tanks

\begin{tabular}{|c|c|c|c|c|c|c|c|}
\hline \multirow[b]{2}{*}{ Tank } & \multirow{2}{*}{$\begin{array}{c}\text { Volume } \\
(\text { g.ll })\end{array}$} & \multicolumn{6}{|c|}{ Concentrations of prinzipal nuclides ${ }^{\mathrm{a}}(\mu \mathrm{Ci} / \mathrm{ml})$} \\
\hline & & & ${ }^{134} \mathrm{Cs}$ & ${ }^{136} \mathrm{Cs}$ & ${ }^{137} \mathrm{Cs}$ & ${ }^{140_{\mathrm{Ba}}}$ & ${ }^{3} \mathrm{H}$ \\
\hline \multicolumn{8}{|l|}{ Reactor coolant } \\
\hline bleed $\operatorname{tank} A$ & 77,250 & 1.9 & 6.5 & 0.28 & 28 & 0.09 & 0.23 \\
\hline \multicolumn{8}{|l|}{ Reactor coolant } \\
\hline bieed tank B & 77,250 & 2.8 & 7.6 & 0.29 & 35 & 0.3 & 0.27 \\
\hline \multicolumn{8}{|l|}{ Reactor coolant } \\
\hline bleed $\operatorname{tank} C$ & 77,250 & 3.0 & 7.7 & 0.28 & 35 & 0.29 & 0.29 \\
\hline Neutralizer tank $A$ & 8,780 & 0.15 & 0.56 & 0.01 & 2.5 & 0.07 & - \\
\hline Neutralizer tank B & 8,780 & 0.18 & 0.72 & 0.02 & 3.3 & 0.03 & - \\
\hline $\begin{array}{l}\text { Misc. waste holdup, Auxiliary } \\
\text { Building sump and tank, misc. } \\
\text { sumps }\end{array}$ & 13,500 & 1.0 & 2.4 & 0.08 & 10.1 & 0.80 & 0.98 \\
\hline $\begin{array}{l}\text { Waste evaporator condensate, } \\
\text { contaminated drain tanks }\end{array}$ & 16,200 & $<10^{-1}$ & $<10^{-1}$ & $<10^{-1}$ & $<10^{-1}$ & $<10^{-1}$ & - \\
\hline Totã. & 279,010 & & & & & & \\
\hline
\end{tabular}


being installed in the course of completing the modifications now in progress. The surveillance and personnel exposures associated with these processing actions are compared favorably with radiation levels associated with the stored liquid.

The removal of the stored contaminated water will also provide additional benefit to the surface decontamination effort currently under way in the Auxiliary Building--now precluded by high radiation levels.

\subsubsection{Process description}

The process to be employed for the treatment of the IALW is an extension of that used for low-level water decontamination (Epicor-I) and is based on existing commercial technology currently in practice at numerous nuclear power plants. This process, designated as Epicor-II, uses a liquid radwaste processing system supplied by Epicor, Inc., and is designed to decontaminate radioactive water contained in the Auxiliary Building tanks via filtration and ion exchange.

A simplified schematic flow diagram of the Epicor-II system is presented in Fig. 7. Contaminated water is pumped from the miscellaneous waste holdup tank in the Auxiliary Building to a prefilter in the process which removes particulate radioactive materials and suspended solids. This prefilter also contains a cation exchange resin which is highly effective for removing resin and other cationic radionuclides from the water (removal efficiency, approximately 90\%). Following the prefilter, the solution is passed through two demineralizers placed in series. The first demineralizer also contains cation resin which further decontaminates the solution from cation-sorbing nuclides. The second demineralizer contains mixed resins (cation and anion) which are efficient for both cationic and anionic radionuclides, including cesium and iodine. Should analysis indicate that the radionuclide content of this water is above specifications, the water can be transferred to an off-specification vessel (95,000 gal) for rework. After processing, the water is collected in a clean water-receiving tank which has a capacity of 133,000 gal. Product water below the predetermined limits contained in the plant's technical specifications will be transferred to the TMI-1 or 2 . liquid waste management system to be held for ultimate disposition. 
ORNL DWg 79-15329RI

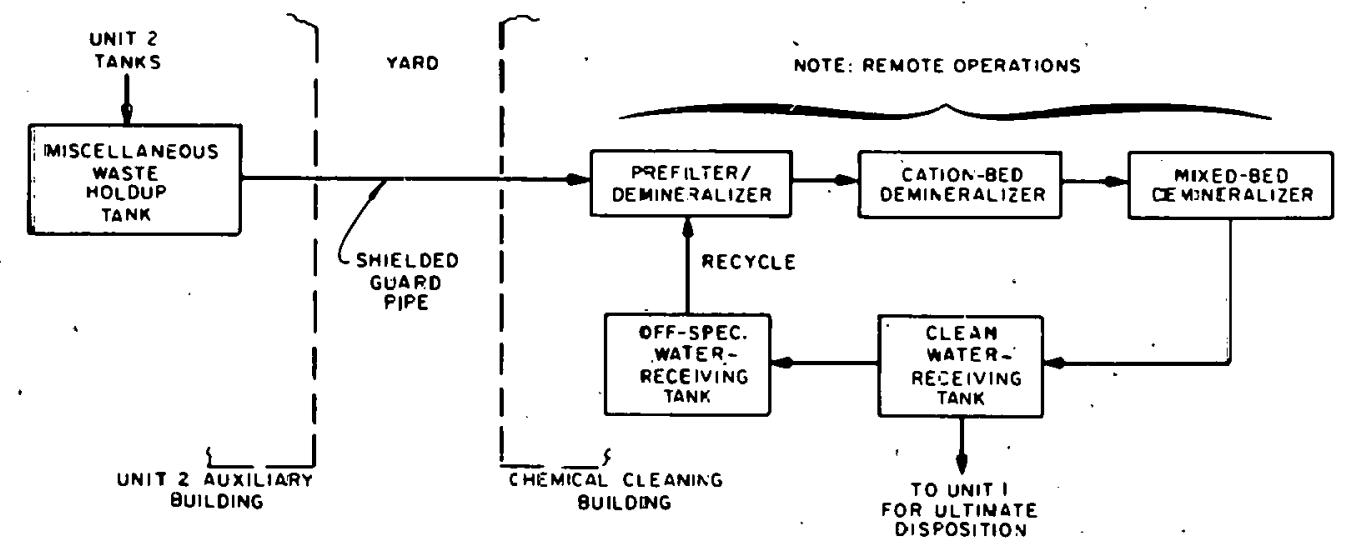

-IQUID WASTE FLOW PATHS

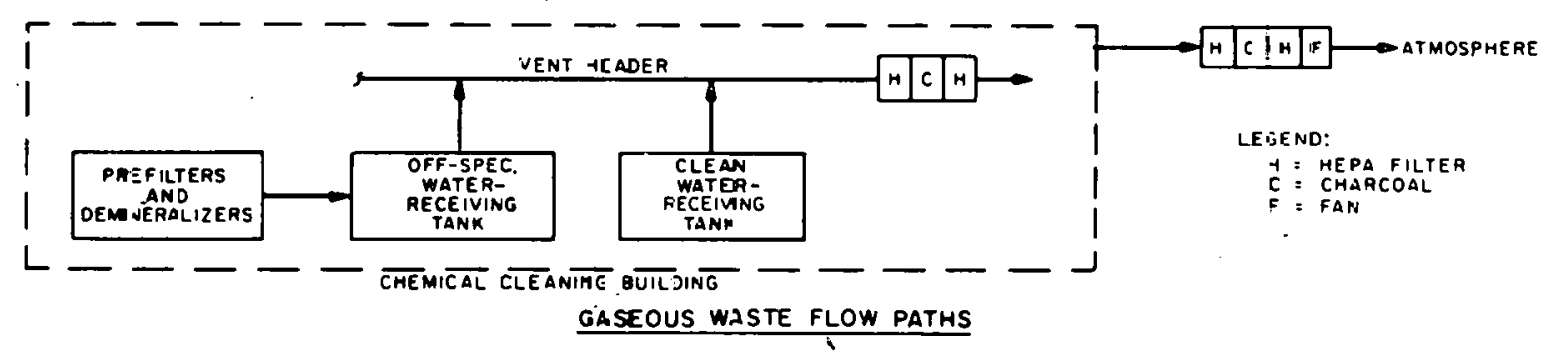

Fig. 7. Flow schematic of Epicor-II processing system. 
Thus far, no decision has been made of the ultimate disposition of this water (to the Susquehanna River, for example) because of political concerns.

The Epicor-II processing of the IALW will be done in the Chemical Cleaning Building, which has been modified to ensure the safety of workers and the general public as the result of more stringent radiation controls. Basically, the modifications to this building were made in the general area of radioactive material containment. The Chemical Cleaning Building has been converted into a low-leakage. confinement area and has been equipped with an exhaust system to maintain the building at a negative pressure. HEPA and charcoal systems have been provided on the ventilation system, which will discharge through a localized stack. All effluents from the process will be subjected to both gaseous and liquid release monitoring. The processing system will be operated entirely by remote means, except for infrequent tasks such as sampling and chemical additions. All remote system operations are controlled from the TV Monitor Control Building, which is located adjacent to the Process Building. The remote transfer of spent filters and resins from this position in the Processing Building into shielded casks for removal to the solids staging area can be accomplished and has been incorporated into the design.

\subsubsection{Process environmental assessment}

The Nuclear Regulatory Commission (NRC) has recently submitted an environmental assessment ${ }^{7}$ of the Epicor-II process fur comment. The alternatives to processing the IALW in Epicor-II were addressed in this assessment. The alternatives included (1) transport of the liquid offsite, (2) continued storage of liquid in the TMI-2 Auxiliary Building tanks, and (3) processing the liquid as outlined in the Epicor-II process. The overall conclusion, based on the assessment, is as follows: ${ }^{1}$

We have determined, based on this assessment, that the proposed use of EPICOR-II for the processing of contaminated waste from the TMI Unit 2 auxiliary building will not significantly affect the quality of the human environment. Therefore, the Commission has determined that an environmental impact statement need not be prepared, and that, pursuant to 10 CFR $51.5(\mathrm{c})$, issuance of a negative declaration to this effect is appropriate. 


\subsection{Treatment of High-Activity-Level Water}

The largest volume of water generated from the accident can be regarded as high-activity-level water (HALW), which may be defined as water with a radionuclide concentration in excess of $100 \mu \mathrm{Ci} / \mathrm{m} 1$ based on the ${ }^{137} \mathrm{Cs}$ content.

\subsubsection{Quantity and characteristics}

Water in this category is primarily from two major sources. The first source $(90,000 \mathrm{gal})$ is the water contained in the primary loop coolant circuit which is used to maintain the reactor in a safe condition by removing heat in a natural convection mode. The second source (540,000 gal) includes (1) the water contained in the reactor contalnment structure which resulted from the release of water from the primary cooling circuit during the early phase of the accident, (2) the volume of liquid transferred into the building through the containment spray system, and (3) a large volume of water which was released through miscellaneous equipment (pump seals, space coolers, etc.) during the post-accident period. Depending on the fission product removal efficiency of the EpicorII treatment system, the water in the three reactor coolant bleed tanks may be processed later, if necessary, in this system. Table 2 outlines the volumes of solution and concentrations of the primary radionucilites contained in this material.

In addition to the increased radioactivity contained in this water, the ionic contamination mandates that the water be given special treatment. The major ionic constituent is boron, present at levels up to approximately $2600 \mathrm{ppm}$, which is used as a neutron poison in the coolant circuit. In addition to this element, sodium is also present as the result of spray activation with $\mathrm{NaOH}$ solution. Table 3 presents significant information related to the chemical and ionic characteristics of the HALW solution.

\subsubsection{Necessity for emergency tankage}

Soon after the accident, it was recognized that additional tankage would be required to receive the HALW accumulating in the Reactor Containment Building. There was considerable concern that the water level in the 
Table 2. Volumes of solution and concentrations of principal nuclides contained in high-activity-level water and precipitate ${ }^{\mathrm{a}}$

\begin{tabular}{|c|c|c|c|c|}
\hline & \multirow{2}{*}{$\underset{\text { Poop }}{\text { Primary }}$} & \multicolumn{3}{|c|}{ Reactor Containment Building ${ }^{c}$} \\
\hline & & Top & Middle & Bottom \\
\hline Volume, gal & 90,000 & $一$ & $-540,000-$ & \\
\hline \multicolumn{5}{|c|}{ Radionuclide content of water, $\mu \mathrm{Ci} / \mathrm{ml}$} \\
\hline $\begin{array}{l}137 \mathrm{Cs} \\
134 \mathrm{Cs} \\
90 \mathrm{Sr} \\
89 \mathrm{Sr} \\
129 \mathrm{I} \\
131 \mathrm{I} \\
140 \mathrm{Ba} / 140 \mathrm{La} \\
3 \mathrm{H} \\
\text { Gross } \alpha\end{array}$ & $\begin{array}{l}90-110 \\
18-22 \\
17-19 \\
305-330 \\
0.5-0.6 \\
4-5\end{array}$ & $\begin{array}{c}176 \\
40 \\
2.7 \\
43 \\
0.079^{\mathrm{d}} \\
0.012 \\
0.09 \\
1.03 \\
3.4 \pm 1.6^{\mathrm{e}}\end{array}$ & $\begin{array}{c}179 \\
40 \\
2.9 \\
41 \\
0.080^{\mathrm{d}} \\
0.012 \\
0.078 \\
1.05 \\
1.2 \pm 1.3^{\mathrm{e}}\end{array}$ & $\begin{array}{c}174 \\
40 \\
2.8 \\
42 \\
0.076^{\mathrm{d}} \\
0.013 \\
0.14 \\
1.01 \\
5.4 \pm 2.0^{\mathrm{e}}\end{array}$ \\
\hline \multicolumn{5}{|c|}{$\begin{array}{l}\text { Radionuclide content of precipitate, } \mu \mathrm{Ci} / \mathrm{ml} \\
\text { (on total } \mathrm{ml} \text { of bottom sample) } f, g\end{array}$} \\
\hline $\begin{array}{l}95 \mathrm{Nb} \\
95 \mathrm{Zr} \\
103 \mathrm{Ru} \\
129 \mathrm{mTe} \\
131 \mathrm{I} \\
134 \mathrm{Cs} \\
137 \mathrm{Cs} \\
140 \mathrm{Ba} / 140 \mathrm{La} \\
89+90 \mathrm{Sr}\end{array}$ & & & & $\begin{array}{l}0.13 \\
0.05 \\
0.06 \\
0.40( \pm 0.17) \\
0.013 \\
0.015 \\
0.064( \pm 0.020) \\
0.04 / 0.11 \\
2.78 \text { (one } \\
\text { sample on } 1 y)\end{array}$ \\
\hline
\end{tabular}

Radionuclide content of surface deposit on painted steel plug, $\mu \mathrm{Ci}$ :

$$
\begin{array}{lll}
95 \mathrm{Nb}-1.7 & 125 \mathrm{Sb}-0.5 & 131 \mathrm{I}-0.3 \\
103 \mathrm{Ru}-0.6 & 125 \mathrm{~m}_{\mathrm{Te}}-0.5 & 134 \mathrm{Cs}-0.5 \\
106 \mathrm{Ru}-0.4 & 127 \mathrm{~m}_{\mathrm{Te}}-7.8 & 137 \mathrm{Cs}-2.1 \\
113 \mathrm{Sn}-0.2 & 129 \mathrm{~m}_{\mathrm{Te}}-23.6 & 144 \mathrm{Ce}-0.2
\end{array}
$$

${ }^{b}$ As of July 17, 1979.

${ }^{\mathrm{C}}$ As of August 28, 1979. Samples from top and middle--1ight yellow solution; sample from bottom--greenish with dirty green precipitate. All samples have a similar radiation level; $\mathrm{pH}$ is 8.1 (as measured in the top sample).

$\mathrm{d}_{\text {Units }}$ are $\mu \mathrm{g} / \mathrm{ml}$.

ennits are $\mathrm{dpm} / \mathrm{ml}$.

${ }^{\text {Average of two samples. }}$

${ }^{\text {As of August 29, } 1979 .}$ 
Table 3. Chemical and ionic characteristics of highactivity-level waste solution and precipitate

\begin{tabular}{|c|c|c|c|}
\hline \multirow{2}{*}{ Element } & \multirow{2}{*}{\multicolumn{3}{|c|}{ Containment vessel liquid (pool) }} \\
\hline & Top & & Bottom \\
\hline \multicolumn{4}{|c|}{ Sample concentration, $\mu \mathrm{g} / \mathrm{ml}(\mathrm{ppm})$} \\
\hline A1 & 3 & 3 & 3 \\
\hline B & 1950 & 2200 & 1900 \\
\hline $\mathrm{Ca}$ & 10 & 10 & 8 \\
\hline C1 & 10 & 15 & 8 \\
\hline Cs & $0.6^{\mathrm{a}}$ & $0.7^{\mathrm{a}}$ & $0.7^{\mathrm{a}}$ \\
\hline $\mathrm{Cu}$ & $\leq 0.2$ & $\leq 0.2$ & 10 \\
\hline $\mathrm{Fe}$ & 0.6 & 1.1 & 1.8 \\
\hline K & 4 & 4 & 4 \\
\hline $\mathrm{Li}$ & $1.6^{\mathrm{b}}$ & $1.6^{\mathrm{b}}$ & $1.4^{\mathrm{b}}$ \\
\hline $\mathrm{Na}$ & 1080 & 1200 & 1200 \\
\hline $\mathrm{Ni}$ & $\leq 0.2$ & $\leq 0.2$ & 3 \\
\hline$P$ & 0.3 & 0.3 & 0.2 \\
\hline $\mathrm{Rb}$ & 0.3 & 0.3 & 0.3 \\
\hline S & 9 & 8 & 7 \\
\hline $\mathrm{Zn}$ & 0.5 & 0.5 & 0.4 \\
\hline Pu. & $0.010^{C}$ & $0.011^{c}$ & $0.033^{C}$ \\
\hline U & $7^{c}$ & $13^{c}$ & $28^{c}$ \\
\hline \multicolumn{4}{|c|}{$\begin{array}{l}\text { Solids from bottom sample, } \mu \mathrm{g} / \mathrm{ml} \\
\text { (ml of total bottom sample) }\end{array}$} \\
\hline In & & & 0.16 \\
\hline $\mathrm{Cu}$ & & & 54. \\
\hline A1 & & & 7 \\
\hline $\mathrm{Ca}$ & & & $\leq 2$ \\
\hline
\end{tabular}

\footnotetext{
${ }^{\mathrm{a}}$ Fission product.

$b_{L i} ;>99 \%{ }^{7} \mathrm{Li}$.

$\mathrm{C}_{\mathrm{ppb}}$, not $\mu \mathrm{g} / \mathrm{ml}$.
} 
building might rise high enough to flood and thereby prevent operation of some of the vital instruments that monitor and control the reactor. These instruments had not been designed for operation in a hostile environment of high radiation fields and submergence in liquids. Subsequently, a tank farm was designed and installed in the fuel storage pool A contained in the Unit 2 Fuel Handling Building. The original scheduled time for this project was 90 days; however, some acceleration of the schedule was required when the leakage rate increased and it appeared that 50,000 gal of primary coolant might have to be transferred to one of the primary coolant bleed tanks. But, two major leaks were repaired, and this transfer of primary coolant was deemed unnecessary.

The design of the tank farm incorporated six tanks with a total capacity of 110,000 gal. Two 25,000-gal tanks were installed near the bottom of the pool and connected to each other with a standpipe for which devices were to be designed later for sampling and solution transfer. Figure 8 is a photograph of these tanks taken during installation in the fuel storage pool. Four 15,000-gal tanks, installed above the 25,000-gal vessels, were connected to a second standpipe. Shielding for all vessels was provided by installing concrete slabs on the top of the pool structure. An independent off-gas treatment system was also installed on top of the tanks to decontaminate any gaseous effluent that might be evolved during tank operations.

Fortunately, the tank farm system was not needed for its original purpose. This eliminated the potential risk of transferring additional liquid oul of the Containment Building (into the tank farm) and, thereby, increasing the inventory of iodine in a structure external to the reactor system. The decision had been made not to disturb the solution in containment so the 8-day ${ }^{131}$ I could decay to safe 1 imits (see Sect. 3.4.3).

The tank farm will be utilized as an integral part of the HALW treatment system.

\subsubsection{Processing justification}

In order to proceed with the recovery of the reactor system, the liquid being held in the Containment Building will require removal and treatment. Currently, this liquid is standing at a depth of approximately 7-1/2 to $8 \mathrm{ft}$ 
PHOTO B-3925-40

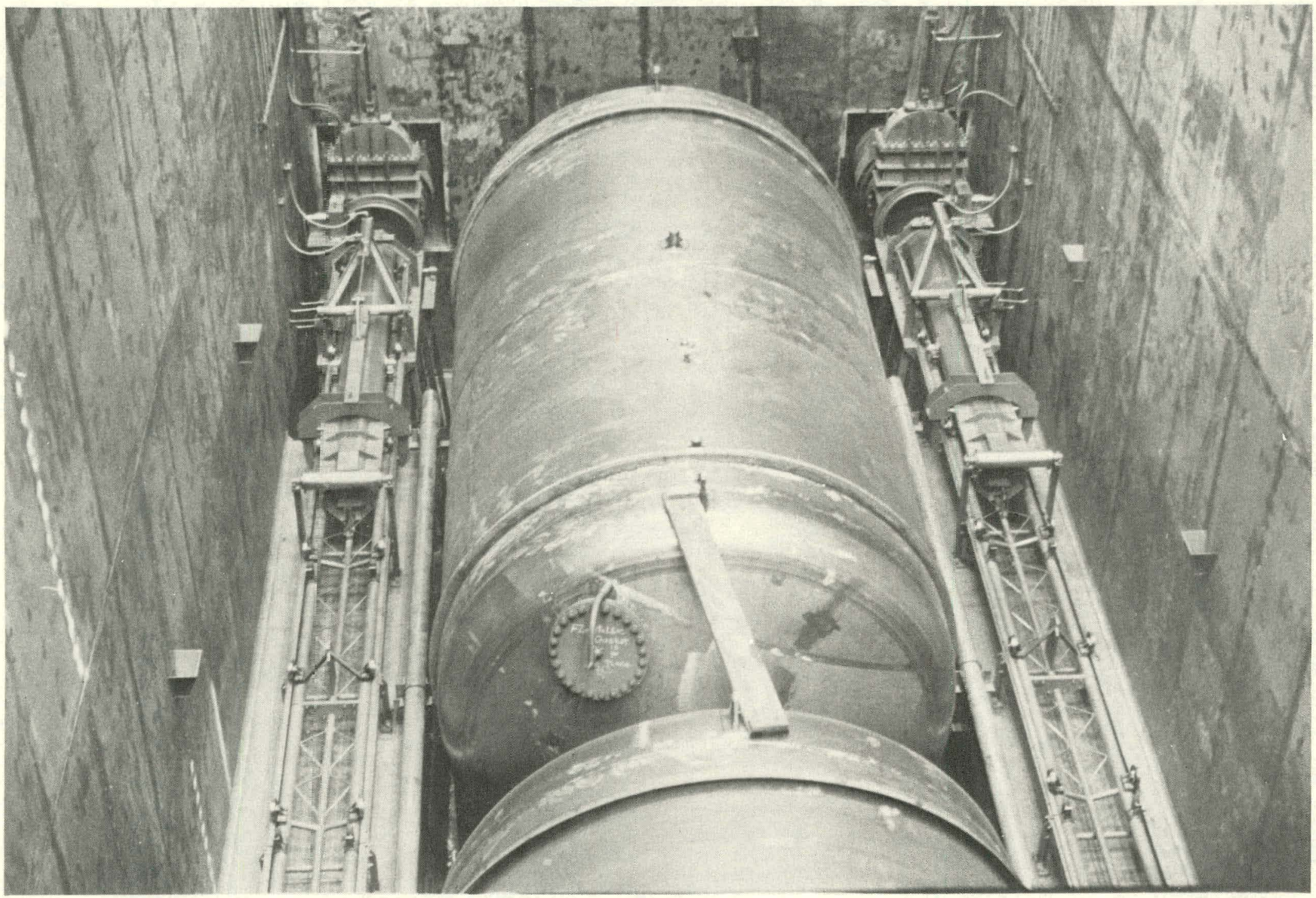

Fig. 8. Tank farm in the T:II-2 fuel storage pool during installation. 
and is covering several components, including instruments. Although the leakage of water into the containment area has been minimized, the possibility for increased leakage continues to exist. In the early phases of the accident, the water in containment had ${ }^{131}$ I concentrations estimated to be of the order of $10^{4} \mu \mathrm{Ci} / \mathrm{ml}$. Because of this factor, every effort was made to avoid disturbing this solution until the radioiodine had been allowed to decay. Figure 9 shows the fission product decay curves, based on the analysis of primary coolant, for the radioactive nuclides that were of greatest concern with regard to treatment of the solution and indicates the most desirable processing period.

\subsubsection{Flowsheet development}

Because of the unique nature of the water to be decontaminated, certain phases of the development of a flowsheet were required. The first phase of the flowsheet development work involved the selection of a suitable exchange medium for the processing of this solution. Limited samples of actual TMI primary loop water were tested in an $\mathrm{ORNL}^{2}$ hot cel1 to establish the characteristics of sorbents believed to be selective for the predominant ${ }^{134-137} \mathrm{Cs}$ and ${ }^{89-90} \mathrm{Sr}$ isotopes. A total of seven materials, both organic and inorganic ion exchange sorbents, were tested (Table 4). Results from these tesls established that one of the zeolites, AW-500 (an inorganic exchanger), was highly selective for the cesium isotopes under the conditions prevailing at TMI and that Dow HCR-S, an organic resin, would be suitable for selection of the strontium isotopes. Following these studies, a series of smal1-scale column runs was made to verify the number of column volumes that could be expected from the various sorbents using solutions adjusted to TMI's water conditions. Information resulting from these studies was then applied to a "scale-up" computer program at the Savannah River Laboratory to provide information on design of the ion exchange columns. Perlinent information yielded by these studies is presented in Figs. 10 and 11.

\subsubsection{Process design objectives and criteria $^{8}$}

Chem-Nuclear Systems, Incorporated (CNSI), was awarded a contract from the General Public Utilities Services Corporation to provide a flowsheet for 
ORNL Dwg 79-13239A

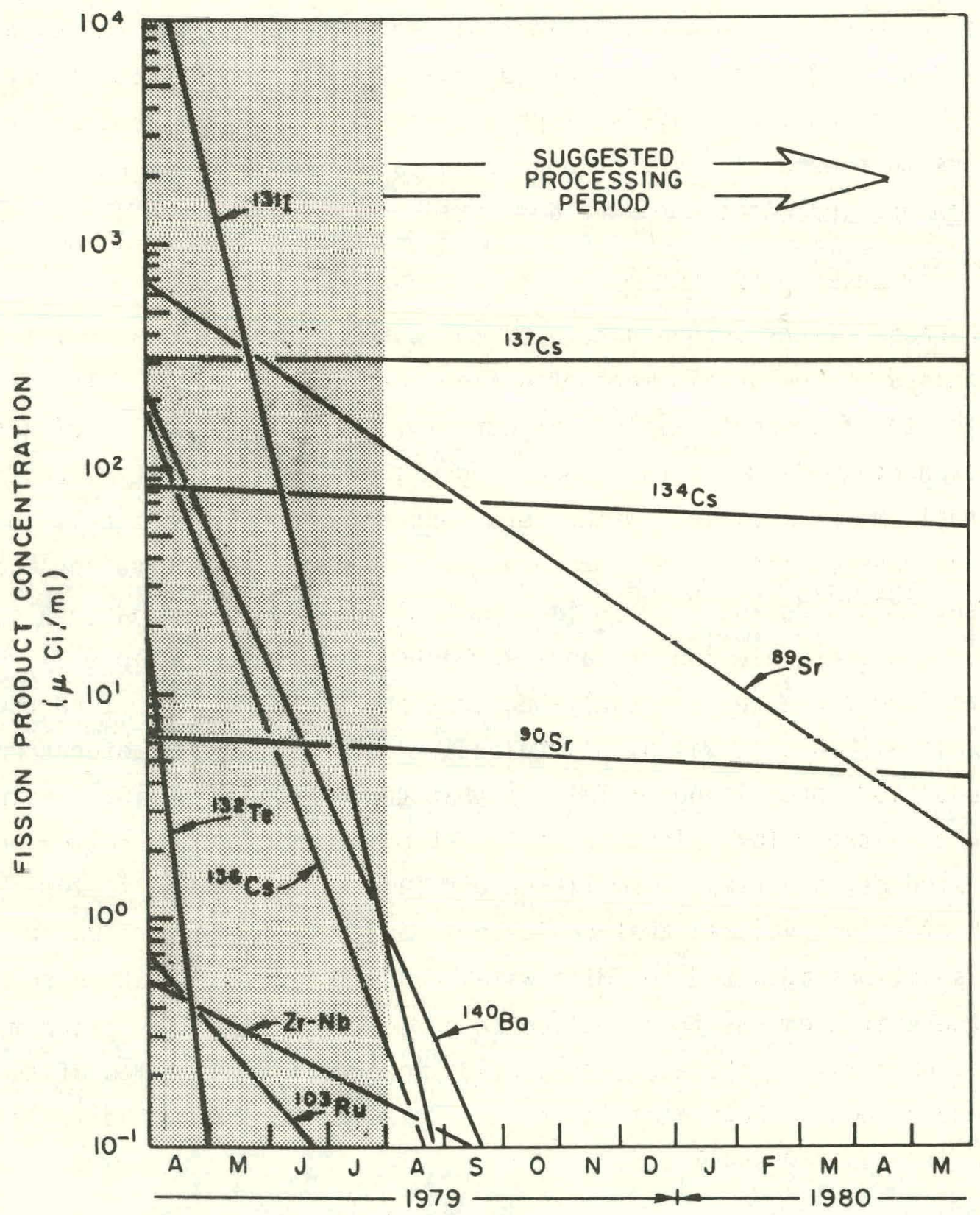

Fig. 9. Fission product decay in the TMI-2 primary loop. 
Toble 4. Distribution coefficients $\left(K_{d}\right)$ for primary coolont

\begin{tabular}{|c|c|c|c|c|c|c|c|c|}
\hline \multirow[b]{2}{*}{ Exchanger } & \multicolumn{3}{|c|}{ Sr $\quad K_{d}$} & \multicolumn{3}{|c|}{ Cs $K_{d}$} & \multirow[b]{2}{*}{ Final pH } & \multirow{2}{*}{$\begin{array}{l}\text { Phose } \\
\text { ratio } \\
(\mathrm{ml} / \mathrm{g})\end{array}$} \\
\hline & $5 \mathrm{~min}$ & $2 \mathrm{hr}$ & $\begin{array}{c}\text { Second } \\
\text { poss }\end{array}$ & $5 \mathrm{~min}$ & $2 \mathrm{hr}$ & $\begin{array}{l}\text { Second } \\
\text { poss }\end{array}$ & & \\
\hline $\begin{array}{l}\text { HCR-S } \\
\text { IR-200 } \\
\text { Z-900 } \\
\text { AW-500 } \\
\text { Clino. } \\
\text { Glass } \\
\text { Charcoal }\end{array}$ & $\begin{array}{r}50 \\
120 \\
\sim 0 \\
\sim 2 \\
22 \\
96 \\
20\end{array}$ & $\begin{array}{r}230 \\
290 \\
50 \\
100 \\
96 \\
250 \\
50\end{array}$ & $\begin{array}{c}\text { Primary } \\
20 \\
28 \\
39 \\
-- \\
130 \\
54 \\
60\end{array}$ & $\begin{array}{r}\text { ater as } \\
3700 \\
85 \\
280 \\
180 \\
135 \\
160 \\
0\end{array}$ & $\begin{array}{c}\text { eived - } \\
8700 \\
200 \\
1800 \\
1300 \\
990 \\
440 \\
0.7\end{array}$ & $\begin{array}{c}50 \mathrm{ppm} \\
>330 \\
250 \\
1400 \\
-- \\
3000 \\
400 \\
2\end{array}$ & $\begin{array}{l}3.6 \\
8.3 \\
-- \\
-- \\
8.6 \\
8.6 \\
8.7\end{array}$ & $\begin{array}{c}27 \\
71 \\
144 \\
136 \\
67 \\
68 \\
42\end{array}$ \\
\hline $\begin{array}{l}\text { HCR-S } \\
Z-900 \\
\text { AW-50O. } \\
\text { Clino. } \\
\text { Gloss } \\
\text { No Titonate }\end{array}$ & $\begin{array}{r}0 \\
\sim 0 \\
27 \\
20 \\
55 \\
1500\end{array}$ & $\begin{array}{r}265 \\
--5 \\
54 \\
42 \\
270 \\
4200\end{array}$ & $\begin{array}{c}\text { imary we } \\
19 \\
-- \\
86 \\
40 \\
38 \\
16\end{array}$ & $\begin{array}{r}+50^{\circ} \\
40 \\
140 \\
238 \\
75 \\
70 \\
92\end{array}$ & $\begin{array}{r}\text { OOH to } \\
48 \\
-- \\
1400 \\
400 \\
350 \\
70\end{array}$ & $\begin{array}{c}4000 \mathrm{p} \\
9000 \\
-- \\
2200 \\
1300 \\
320 \\
70\end{array}$ & $\begin{array}{l}n \mathrm{No} \\
8.5 / 3.7 \\
- \\
9.7 \\
10.1 \\
10.1 \\
10.1\end{array}$ & $\begin{array}{l}56 \\
55 \\
54 \\
60 \\
56 \\
58\end{array}$ \\
\hline
\end{tabular}


ORNL Dwg 79-13595

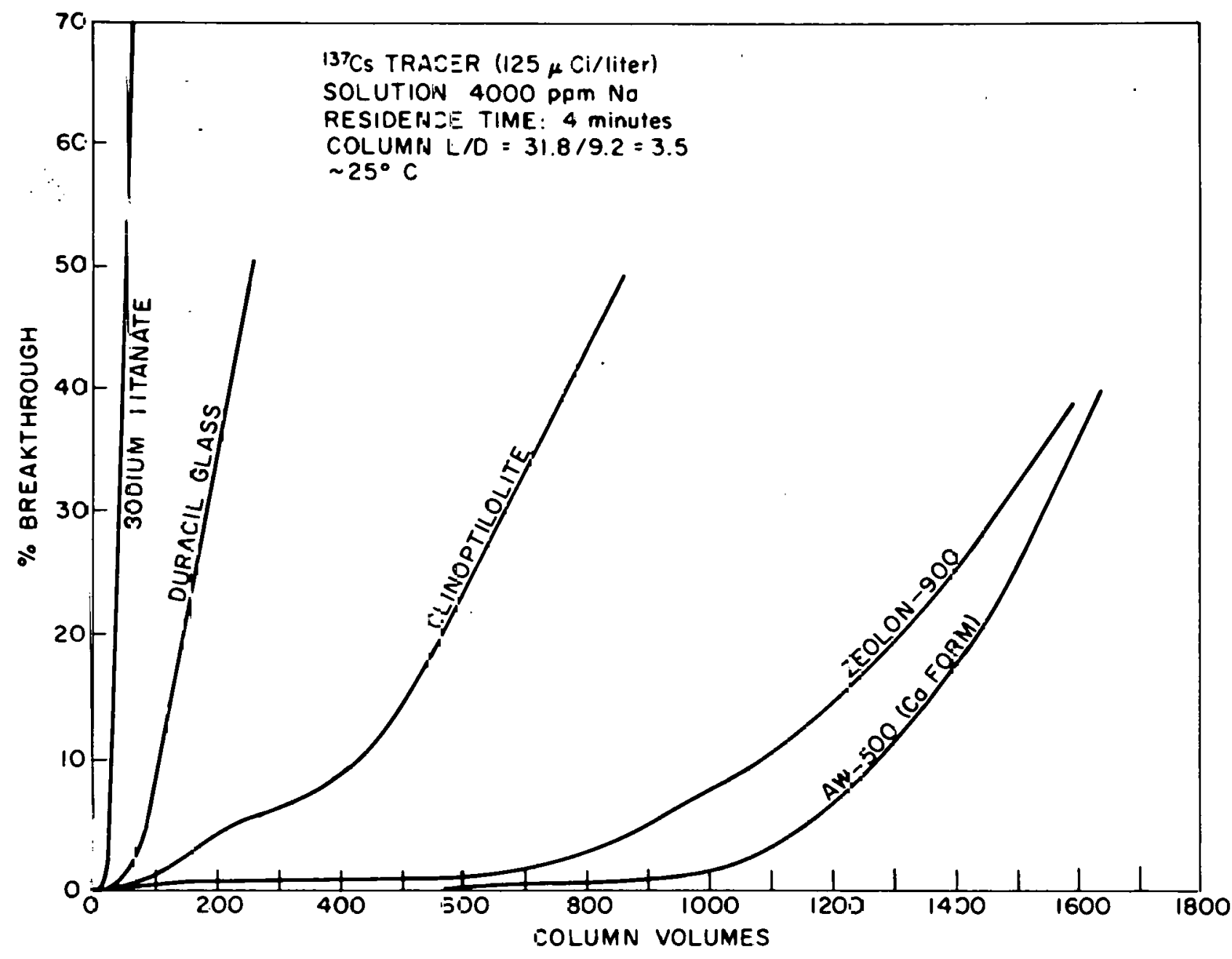

Fig. 10. Small-co-umn ioading tests of ion exchange materials with synthetic TMI-2 pr'mary loop water and 13 ? Cs tracer. 


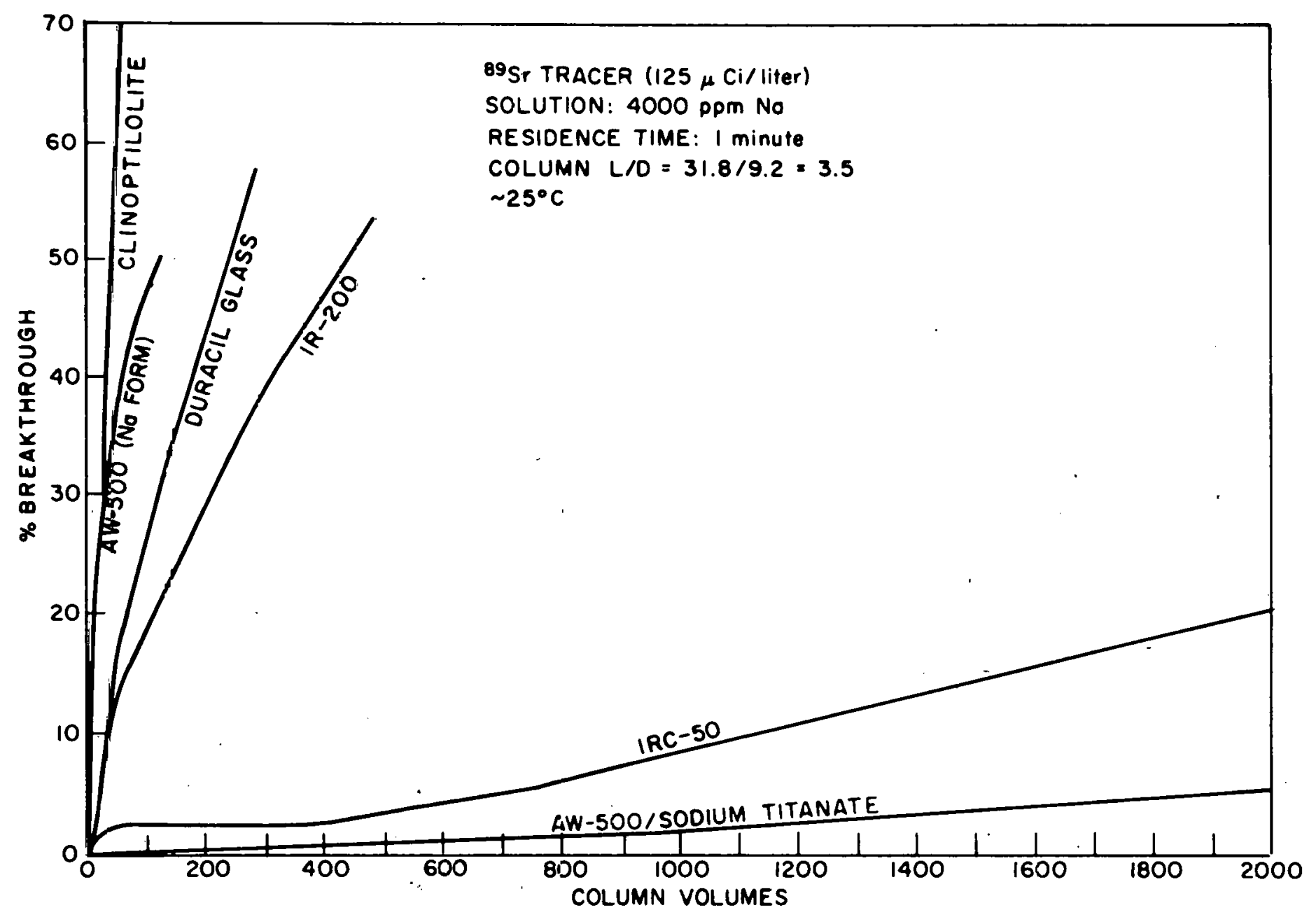

Fig. 11. Smal1-volume loading tests of jon exchange materials with synthetic TMI-2 primary loop water and ${ }^{89} \mathrm{Sr}$ tracer. 
the treatment of HALW. CNSI then employed Allied-General Nuclear Services to assist them in the design of a suitable system.

A series of design objectives was drafted to provide a system that

1. was totally integrated and as independent as possible from existing waste and off-gas systems at TMI,

2. could remove the fission products in the water to a level that would meet designated TMI release requirements,

3. could be operated with a minimum of exposure to personnel and a negligible risk to the general public, and

4. would accomplish these objectives in a timely and cost-effective. manner.

The following design concepts were used in order to accomplish these objectives:

1. CNSI has designated an ion exchange system for the removal of radionuclides from the water.

2. The ion exchange columns are to be located underwater in the spent fuel pool, which will provide for containment and personnel shielding.

3. To the extent possible, all-welded stainless steel construction is specified to minimize the potential for leakage.

4. Lead or equivalent shielding is pruvideld for plpes, valvés, and vessels (except those located underwater) that could carry contaminated water.

5. Contaminated water from the containment. sump is to be filtered, collected in one of twn hatch tanks, sampled, and thon pumper continuously to the ion exchange s.ystem.

6. Two parallel filters and ion exchange systems are to be used to provide capacity and to ensure continuous operation.

$\%$ Continuous effluent monitoring systems are to be provided to ensure adequate control of the operation.

8. The valving systems are to be designed to minimize the impact of operator error.

9. The system is to be designed for a minimum of 2 years of service. 


\subsubsection{System and process description}

The conceptual system design consists of the following elements:

1. a feed filtering system;

2. four feed tanks with independent mixing, sampling, levelmeasuring, and feed-pumping capability;

3. two parallel primary ion exchange trains, each comprised of three $7-\mathrm{ft}^{3}$ beds of zeolite exchange media;

4. two parallel ion exchange beds containing organic cation resin for removal of strontium;

5. a continuous monitoring system and sampler system for control of bed loading;

6. a secondary containment system for the filters, primary and cation beds, and radiation shielding for piping, valves, samplers, and monitors;

7. a carbon-cation "filter" bed for removal of trace fission products;

8. a mixed-resin ion exchange polishing bed for removal of trace fission products that are not trapped on the primary or cation beds;

9. a 195- $\mathrm{ft}^{3}$ ion exchange bed for removal of boron (should this be required);

10. two monitoring tanks for collecting and sampling the treated water prior to discharge and storage;

11. an off-gas system for treating and filtering gases and air from the system;

12. assoclated pipiny, valving, and struetural supports required for placement of the system components; and

13. auxiliary systems, including underwater ion exchange column storage, a column dewatering system, a system for solidifying the resin beds with concrete, and analytical equipment.

Feed filtering system. This system consists of two parallel underwater filter units. Each unit is a cluster of $5-\mu$ cartridge filters protected by perforated metal screens and contained in a 24-in.-diam $\times$ 54-in.long column. Inlet, outlet, and vent connections are made with Hansen quick-release valved couplings which are remotely operated from the top

A About 90 to $95 \%$ of the strontium and essentially all of the cesium will be loaded on the zeolite. 
of the pool. A gamma monitor, located in a dry well adjacent to the filters, and inlet and outlet pressure gauges are provided to monitor and control solids loading. Load limits will be based on available system pressure and/or the surface dose limit for the filter cask. The capacity of each filter is about $15 \mathrm{gpm}$. Feed will be pumped from the reactor containment sump, through the filters, and into the feed tanks on a batch basis.

Feed tank system. This system consists of four of the 15,000-gal tanks located in the emergency tank farm. Each tank will have an airlift system for circulating the feed solution and for raising it to a small pump head tank (approximately 8 in. diam $x+3 \mathrm{ft}$ long). A sampler will be provided on each tank to permit characterization of the feed prior to sending it to the ion exchange system. Level-measurement instruments are also provided. Feed will be pumped to the ion exchange columns using one of two seal-less, magnetically coupled pumps rated at approximately $15 \mathrm{gpm}$ each. The samplers, headpots, and pumps will be located in a shielded enclosure.

Primary ion exchange columns. This system consists of six underwater columns (24 in. diam $\times 54$ in. long), each containing $7 \mathrm{ft}^{3}$ of Linde AW-500 zeolite resin. Inlet, outlet, and vent connections are made with remotely operated Hansen couplings (similar to the filter connections). The beds are arranged in two parallel trains of three each, with piping and valves provided to operate either train individually or both trains simultaneously. Loading will be controlled by feed bat.ch size, operating time, effluent sample analyses, and continuous monitoring. Flowmeters are provided for the total feed stream and the individual feed streams to the two parallel trains. The maximum loading per column will be $65,000 \mathrm{Ci}$ (cask limit). These columns are expected to remove greater than $99 \%$ of the cesium and 90 to $95 \%$ of the strontium from the water. When the desired bed loading is achieved on the first bed of the train, the flow to the train will be stopped. The treated water will then be displaced with fresh water (through the downstream beds), and the first bed wi.l1 be disconnected and moved to the storage rack using the pool area crane. The second bed will be disconnected, moved to the first position, and reconnected. Likewise, the third bed will be moved to the second 
position, and finally a fresh bed will be placed in the third position. (Note: This approach is considered to be superior to a valving manifold which would permit rerouting of the streams because it minimizes the potential of a serious operator valving error. A valve switching approach was considered; however, a valving error could result in totally bypassing the primary beds. The current design prevents this from occurring.)

Cation columns. Two additional underwater columns (of the same size and type as the primary columns) are located immediately downstream. These columns are loaded with organic cation resin (probably Dow HCR-S) for removal of residual strontium. Column loading will be 1 imited to $75 \mathrm{Ci}$ of strontium based on primary column effluent monitoring and analysis. The columns are-arranged to be operated singly or simultaneously in parallel. The curie limit is based on restricting the integrated radiation dose to the resin to less than $10^{8}$ rads.

Sampling and monitoring system. As previously described, the feed.. will be collected in batches, sampled and analyzed, and fed continuously to the ion exchange system. Sampling lines are provided on the effluent streams of each of the primary beds and cation beds. A continuous sample flow from each operating bed effluent will be passed through a beta scintillation monitor. A gamma monitor is located on the primary effluent line, and a local area radiation monitor is located near the valve box. Each of the monitors will have an alarm system and a high-radiation trip point which will close an automatic valve of the main feed line, thereby stopping the operation in case of a leak or a serious breakthrough. Shielded samplers are also provided to permit sampling at any time. Continuous sample effluent is routed to the off-gas separator tank.

Containment and shielding. The filters, primary beds, cation beds, and their associated remote connectors and flexible lines are contained in submerged boxes designed to confine any contaminated leakage. Each box is connected to a pump manifold, and a continuous flow of about $10 \mathrm{gpm}$ is maintained through each box. The containment pump effluent is discharged to an additional mixed-bed resin column and is released back into the pool. A large, shielded box is provided for the various valves and piping which are required for feeding, flushing, and venting the columns. This box will 
be located on the edge of the pool, with shielded lines entering and exiting the box from the bottom. Valves will be operated manually using extension handles that penetrate the top of the box. The valves will also be serviced from the top of the box. A separate shielded box will be provided for the column samplers. All lines which are normaliy radioactive, or could potentially be radioactive, are to be shielded. Shielding will be designed to limit the operator dose to 1 $\mathrm{mrem} / \mathrm{hr}$ at contact. Wherever possible, pipe runs will be located underwater to minimize the need for lead shielding.

"Fflter" bed. This is a $10-\mathrm{ft}^{3}$ ion exchange bed containing carbon and cation resin. This bed is intended to remove trace fission products from the water. Load control will be based on the cation effluent monitor and the column radiation level.

Mixed-resin polishing system. This system consists of a $195-\mathrm{ft}^{3}$ bed of mixed anion and cation resins enclosed in a special shielded cask. This unit, which is also intended to remove trace fission products from the cation effluent, will be located above the water. Load control will be based on the cation effluent analysis and the radiation level at the surface of the container.

Boron removal bed. If desired, a $195-\mathrm{ft}^{3}$ resin bed, enclosed in a shielded cask, is provided for boron removal. Effluent samile anlalys is and surface radiation level monitoring will be used to control loading.

Monitoring tank system. Two monitoring tanks of about 20,000-gal capacity will be provided for collecting and sampling the treated water prior to disposal. The tanks will be provided with mixing, level-measuring, and sampling systems, in addition to transfer pumps. Piping will also be provided for recycle of the treated water in the event that it does not meet disposal specifications,

off-gas system. The feed tanks, valve boxes, monitoring tanks, and column vents are connected to this system. The system consists of a separator tank (which also serves as a sampler effluent collector and valve-box drain tank), an electric off-gas heater, a roughing filter, a charcoal bed for iodine retention, two absolute (HEPA) filters, and a centrifugal blower. The discharge of this blower will be monitored and routed to the reactor vent system. A pressure control system is provided for the blower to 
regulate vent system pressure. The separator tank, which will be located in the surge pit and covered with a concrete shield, is equipped with an automatic-level-controlled pump routed back to one of the feed tanks.

Piping and equipment arrangement. The feed pumps, feed samplers, and head pots will be located in shielded enclosures directly over the tank farm area. As previously described, the filters, primary beds, and cation beds are to be located underwater in special containment boxes. These boxes and columns are to be supported along one side of the pool on a structural steel rack which hangs from the edge of the pool. This rack, which also serves to support the system, will include an operating platform from which the remote connectors are to be handled.

Auxiliary systems. A storage rack, sized to handle the projected number of filters and ion exchange beds required to treat the containment sump water, will be provided. A special rack will serve to displace the water from the columns and filters and to dry them prior to loading into the transfer cask. This rack will be located in the cask loading pool. A system for solidifying the filters and ion exchange columns with concrete will also be provided. An additional system will be included for analyzing feed and effluent samples. Gamma and beta proportional counters and the necessary equipment for boron and sodium analysis will be provided as a minimum.

Figures 12-15 show details of the liquid waste (HALW) decontamination system. (The HALW treatment system is in no way related to either Epicor-I or Epicor-II.) 
ORNL Dwg 79-15885R

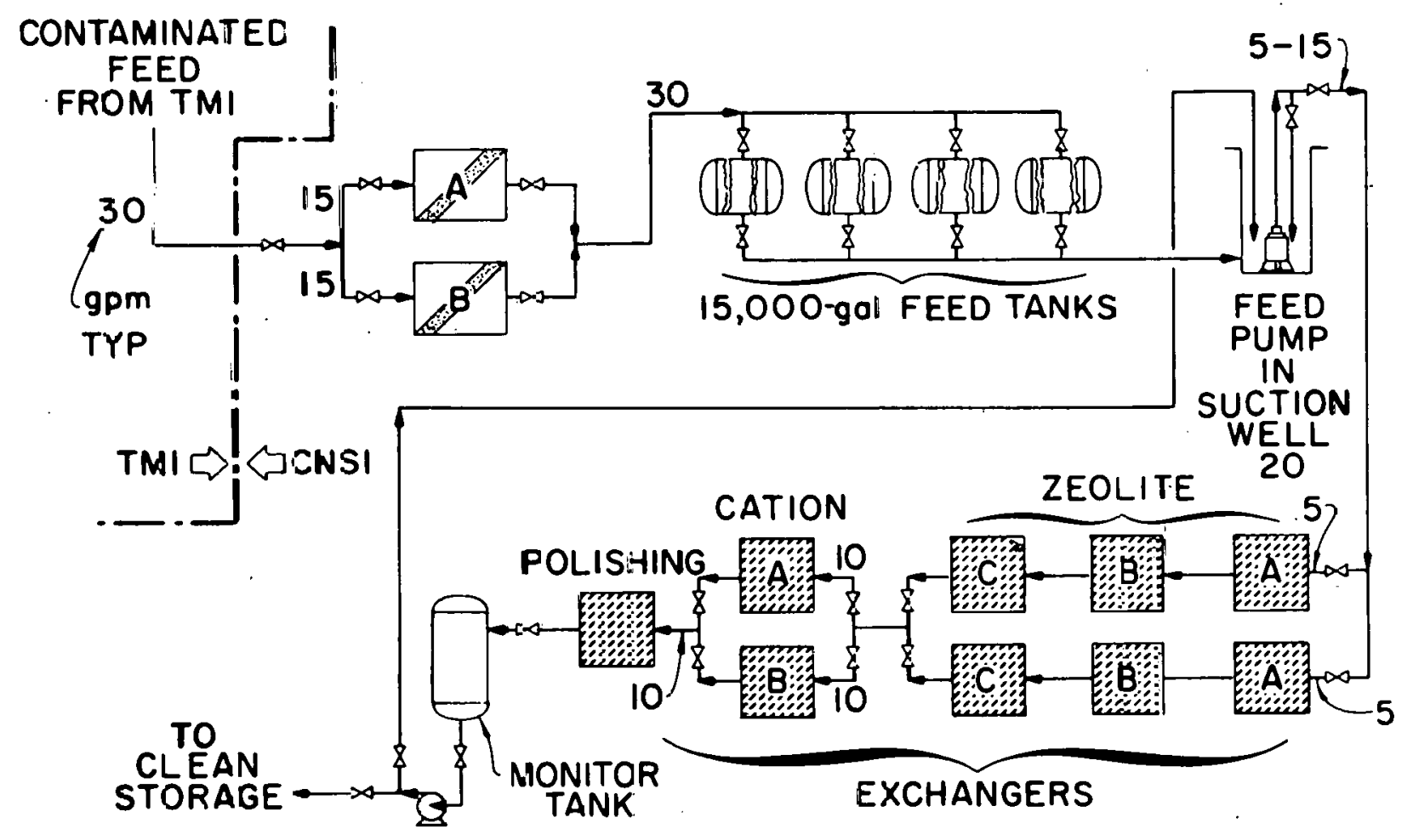

Fig. 12. Liquid waste decontamination flowsheet. 


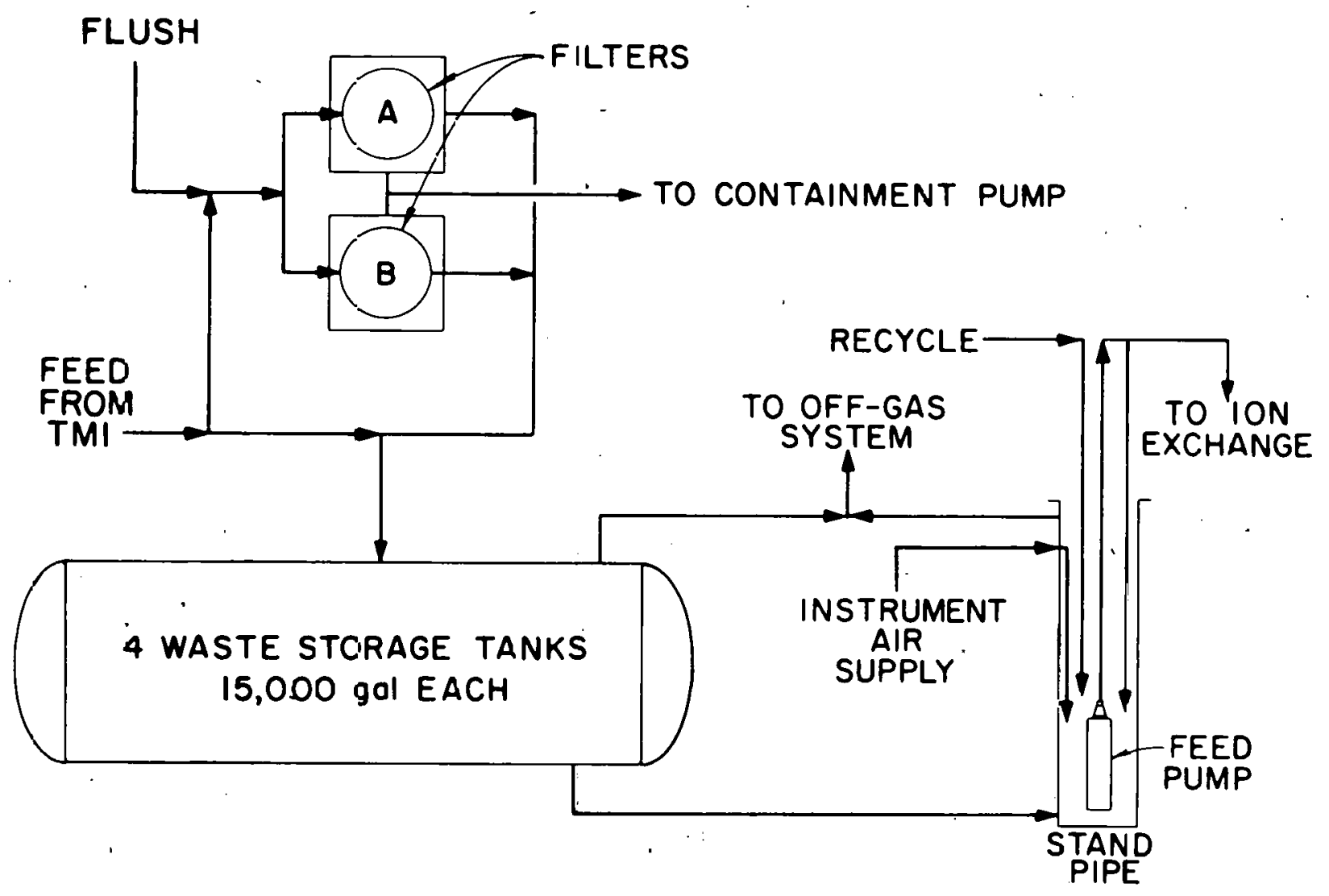

Fig. 13. Feed system details. 


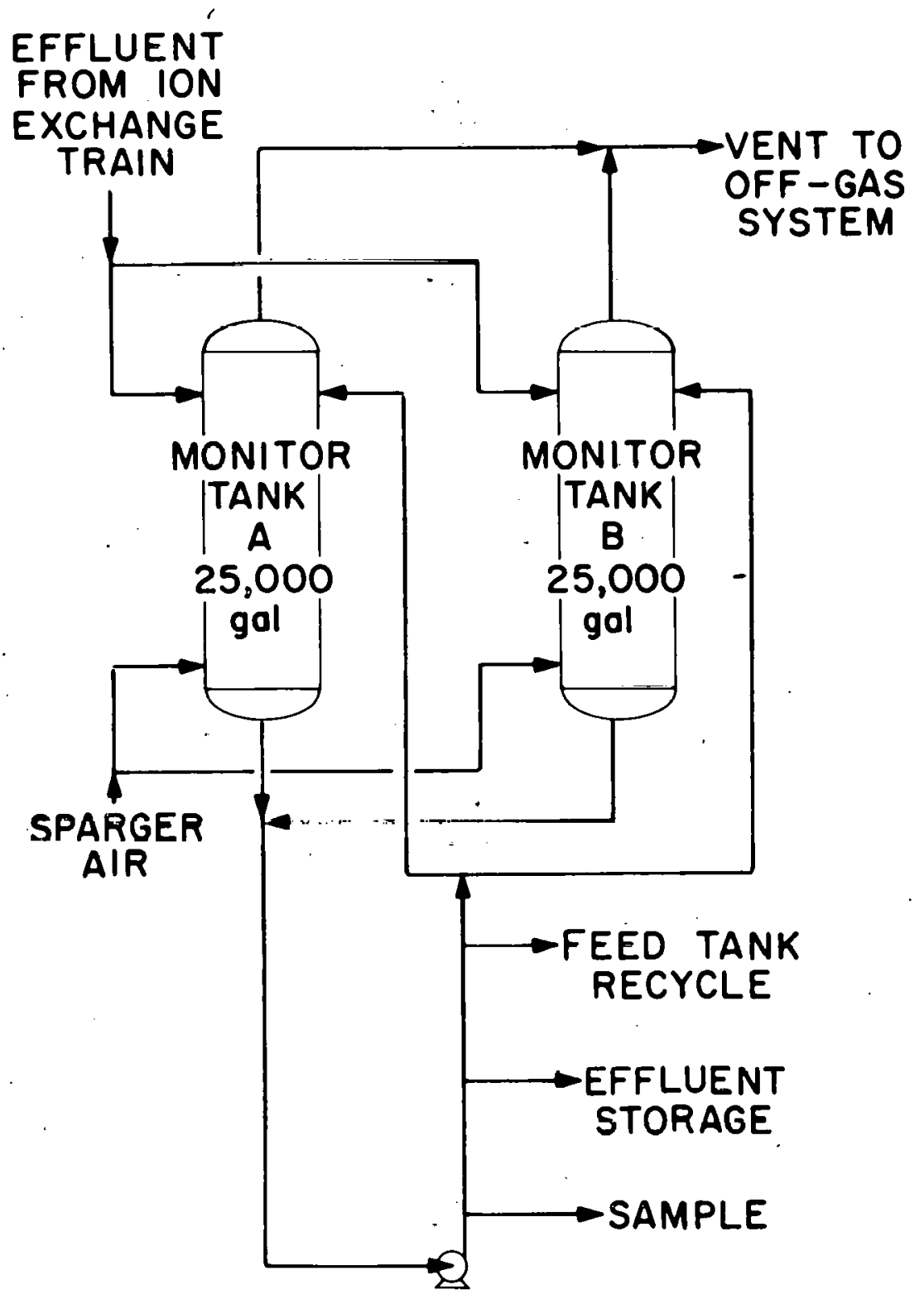

Fig. 14. Monitor tank details. 
ORNL GWg 79-15886RI

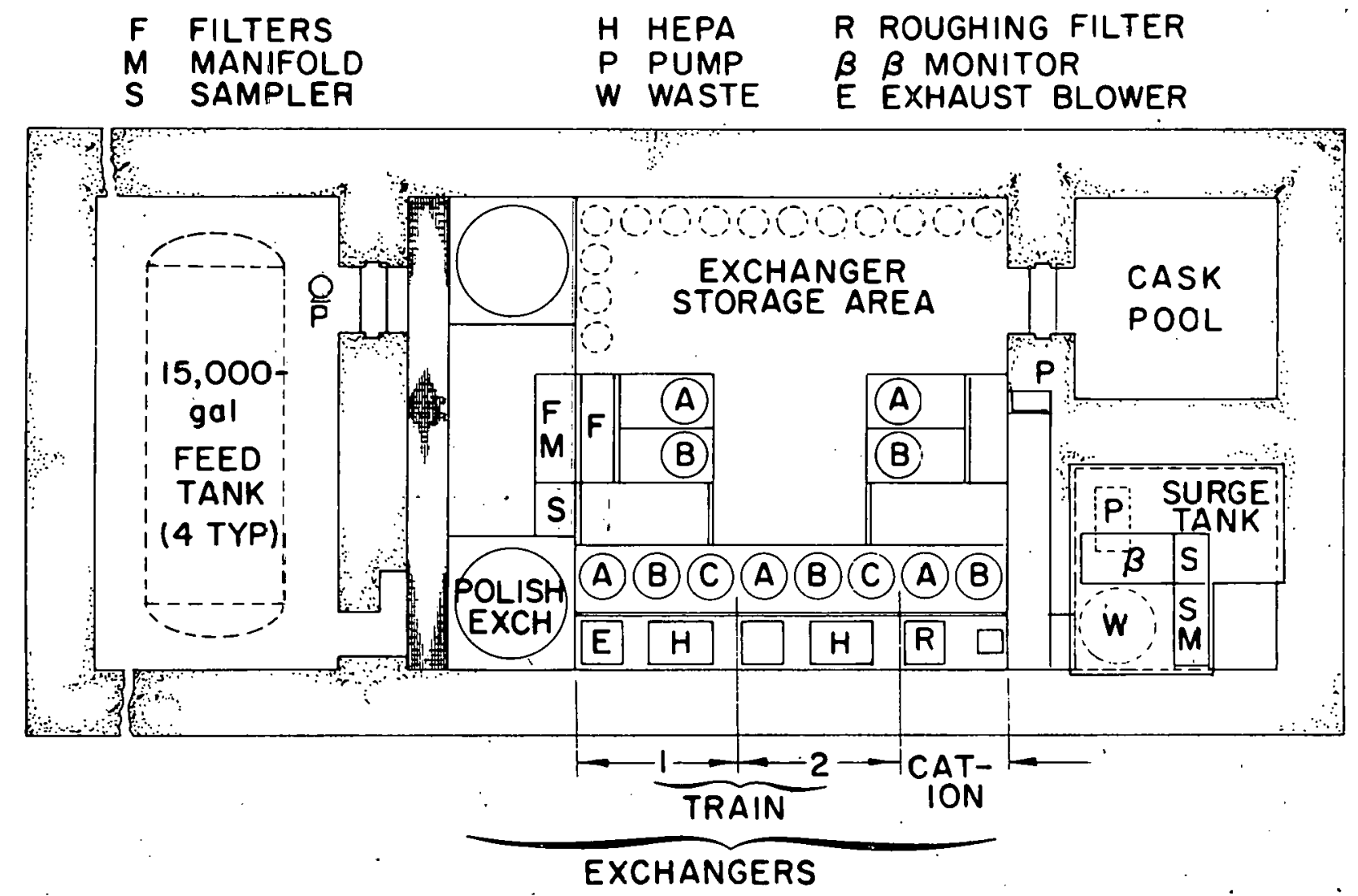

Fig. 15. Layout of liquid waste decontamination equipment. 


\section{RADIOACTIVE SOLID WASTE HANDLING}

Considerable quantities of solid materials will be generated as decontamination of the TMI-2 site and equipment proceeds. Because some experience relative to the decontamination of the affected systems is available and decontamination is currently in progress at the site, this section addresses the generation of solid wastes external to the reactor and the Containment Building. Estimated quantities of solid waste to be generated from this phase of the recovery program is presented in Sect. 5.3.6.

\subsection{Quantities and Characterist.ic.s}

Sulld materlals generated at TMI will be composed of protective clothing, trash, solidified decontamination solutions, dewatered resins, diatomaceous earth, charcoal, and filter cartridges. In order to protect the environment and workers from the radiation and contamination contained on these materials, this material will be packaged in containers of various descriptions such as 55-gal drums, $4 \times 4 \times 8 \mathrm{ft}$ boxes, $180-\mathrm{ft}^{3}$ resin 1 ines or canisters, and resin column shells.

An estimated volume of 60,000 to $70,000 \mathrm{ft}^{3}$ of solid waste ${ }^{9}$ is expected to be generated and shipped over the next 24 months as a result of the decontamination of the Auxiliary and Fuel Handling Buildings and the treatment of various contaminated liquids.

One of the primary sources of solid wastes will be the various sorbents used to concentrate and collect the fission products resulting from the existing and proposed water-treatment system. These materials, predominantiy organic and inorganic exchangers, are contained in mild and stainless steel containers (liners or canisters). To date, only the water in Auxiliary Building 1, which contained a small quantity of post-accident water, has been treated (Epicor-I). Thus, the only existing experience regarding the surption efficlency of the resins is preliminary laboratory data. However, the treatment of that $103,500 \mathrm{gal}$ of water by the Epicor-I system is a good basis for characterizing these resins. Table 5 presents an overall summary of the characteristics of this type of solid waste.

A total of 200 solid waste shipments is projected. About 75 will consist of resin from spent ion exchange beds, and about 125 will consist of other waste including protective clothing and other miscellaneous solid waste generated from cleanup and decontamination activities. 
Table 5. Characteristics of ion exchange canisters resulting from the treatment of low-activity-level water in Epicor-Ia

\begin{tabular}{ccccc}
\hline $\begin{array}{c}\text { Resin } \\
\text { Canister } \\
\text { No. }\end{array}$ & $\begin{array}{c}\text { Volume } \\
\text { treated } \\
\text { (gal) }\end{array}$ & $\begin{array}{c}\text { Feed } \\
\text { (total }\end{array}$ & $\begin{array}{c}\text { Iodine } \\
(\mathrm{C} i \text { ) }\end{array}$ & $\begin{array}{c}\text { Bed } \\
\text { radiation } \\
\text { level }\end{array}$ \\
\hline$D-1$ & 20,000 & 32.6 & 5 & 3.5 \\
$D-2$ & 10,000 & 18.4 & 7.7 & 7.0 \\
$D-3$ & 24,700 & 63.1 & 5.7 & 5.0 \\
$D-4$ & 33,400 & 45.7 & 26.5 & 2.5 \\
$D-5$ & 15,400 & 39.2 & 17.9 & 3.8
\end{tabular}

a Data taken from ref. 10 (treatment began April 11 and water was released by June 6).

Maximum contact readings at surface of container, usually on upper surface.

\subsection{Solid Waste Shipments and Container Information}

Shipments of the solid waste from TMI will be sent to the commercial burial ground site that is located in Richland, Washington, and is operated by the Nuclear Engineering Corporation. Shipments off-site are being handled by CNSI under contract to the General Public Utilities Services Corporation. Shipments will be made in existing licensed packaging systems for materials of this type. A breakdown of the number of shipments currentiy required for material already generated on the site and that projected for the next 24 months is presented in Table 6.

\subsubsection{Transportation equipment availability for shipment}

Many of the solid waste materials are packaged in 55-gal drums or wooden boxes. These containers have external radiation levels which would permit them to be shipped in regular vans/or on flatbed trailers. A shielded van with a capacity of 26,000 ib of payload may be used to accommodate 55-gal drums or other containers with radiation levels up to $1 \mathrm{R} / \mathrm{hr}$.

Seven 14-195* casks are presently available; three additional casks are now being fabricated and are scheduled for completion by 0ctober 1979. These casks are designed and licensed to receive higher-radiation-leve 1

\footnotetext{
*Cask designation. The first part of the designation (i.e., 14) indicates the number of 55-gal drums the cask will hold, while the second number indicates the total cubic feet of space available inside the cask. These are CNSI designations.
} 
Table 6. Shipments required for each category of waste from TMI ${ }^{\text {a }}$

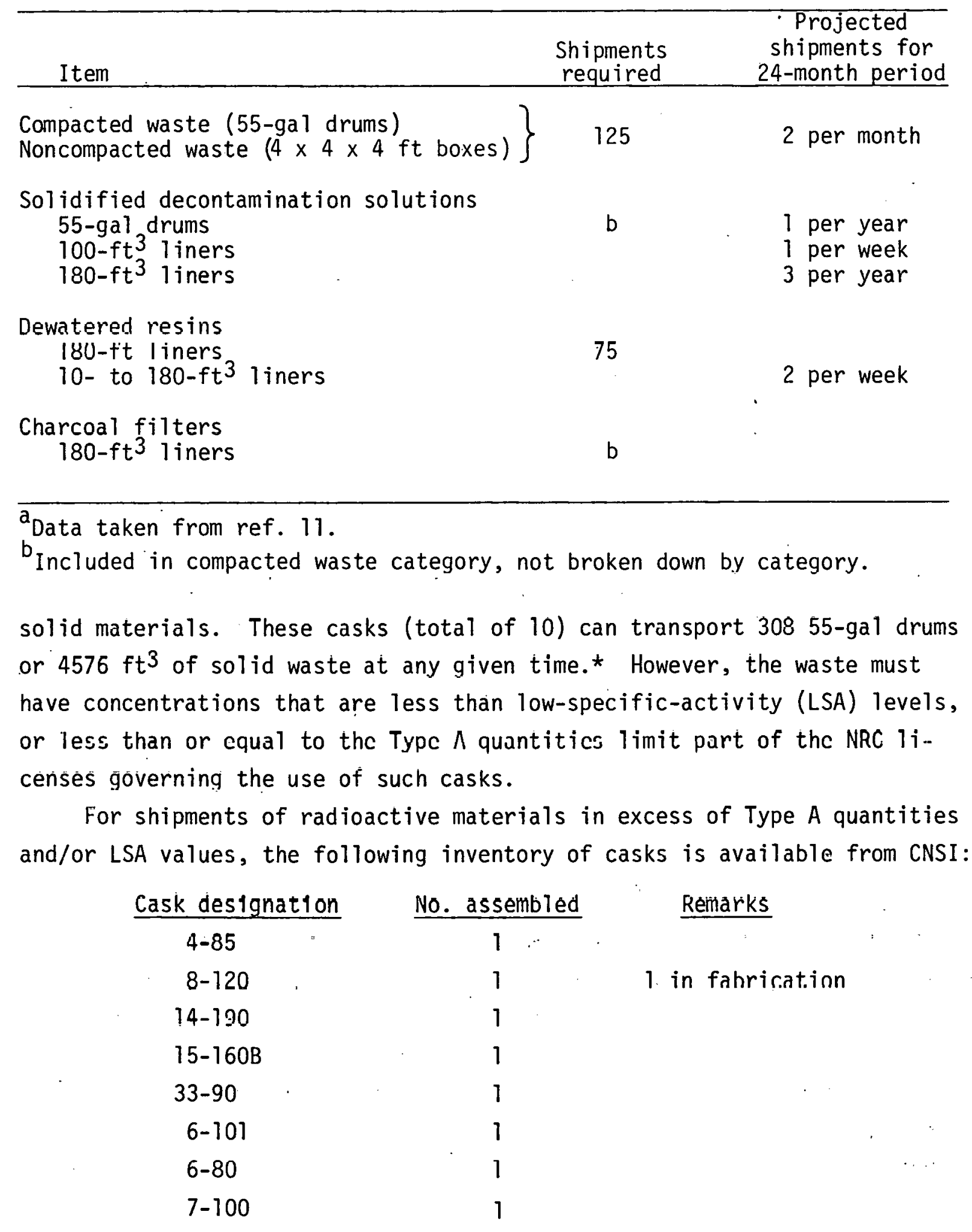

*Data supp Tied by CNSI. ${ }^{12}$ 
Shipping casks originally designed as spent fuel casks are also available as given below:

\begin{tabular}{|c|c|c|}
\hline Cask designation & No. assembled & Remarks \\
\hline $6-4$ & 1 & \\
\hline $1-13$ & 3 & 6 in fabrication \\
\hline $3-55$ & 2 & \\
\hline $4-45$ & 1 & \\
\hline
\end{tabular}

\subsection{Solid Waste Storage Facility Installation}

Because the generation of solid waste at TMI will not keep pace with the shipment of wastes off-site, solid staging areas are required for safety reasons. Information concerned with the design and installation of these systems is presented below.

\subsubsection{Interim solid waste staging facility ${ }^{3}$}

A facility to contain the dewatered radioactive resin generated from the treatment of low-level (Epicor-I) and intermediate-level (Epicor-II) wastes is required until these wastes can be shipped to a burial site. This facility will serve as an interim staging area until a more permanent facility is constructed. This facility, which is presently under construction, has been designed with sixteen 5-ft-diam cells and twelve 84-in. cells to receive the $4-$ by $6-\mathrm{ft}$ and $6-$ by $6-\mathrm{ft}$ resin 1 iners. This structure is installed within the Unit 2 cooling towers desalting basin, backfilled for shielding, and capped with 3-ft concrete plugs. Contact radiation readings are expected to be less than $5 \mathrm{mR} / \mathrm{hr}$ at the surface of the facility.

\subsubsection{Solid waste staging facility ${ }^{3}$}

This facility, currently in the design stage, has been reviewed and approved by Metropolitan Edison and the NRC. It is designed in a modular fashion. Each module consists of $60 \times 84$-in.-diam cells embedded in concrete and capped with 3-ft-thick concrete plugs. Each cell has a drain line to a sump to collect any leakage from the liners installed in the cells. The proposed design meets the seismic requirements of the NRC Regulatory Guịde 1.143. 


\section{FACILITY DECONTAMINATION}

Several major facilities on the TMI site were contaminated with radioactive materials as the result of the accident. These facilities, supporting Unit-2 Reactor, included the Diesel Generator Building, the Auxiliary Building, the Fuel Handling Building, and the Reactor Containment Building. Experience related to the decontamination efforts necessary to restore the first three facilities is presented in this report. Because the exact nature of the conditions within the reactor containment is not known and because no reentry into the building has been made at this time, information presented in this report concerning the decontamination of the last facility is based on a recent planning study.

\subsection{Diesel Generator Building}

On April 10, 1979, contamination of the surfaces of the Diesel Generator Building at the 305- and 280-ft levels was confirmed as the result of a release of liquid from equipment and components within the building. The transferable contamination levels on the affected surfaces ranged from 1000 to $112,000 \mathrm{dpm} / 100 \mathrm{~cm}^{2}$. Airborne activity within the contaminated area, determined with a high volume air sampling device, was about $1.5 \mathrm{x}$ $10^{-8} \mu \mathrm{Ci} / \mathrm{cc}$. The highest radiation level within the area was found to be around the sump pump $(100 \mathrm{mR} / \mathrm{hr})$ serving this facility. By the time the contamination was noted, Westinghouse Nuclear Services Division had already begun construction of an emergency decay-heat removal system within the building. Subsequently, Westinghouse engaged VIKEM Corporation, a commercial decontamination firm, to decontaminate the facility in order to proceed with the installation of the decay-heat removal system. Although this radioactive spill may be regarded as a "minor occurrence" when compared with other TMI-2 facilities affected by the accident, the experience gained from the decontamination exercise was useful in providing information for subsequent decontamination of the other TMI-2 facilities. Information obtained from this decontamination effort (1) increased understanding of the removal efficiency of the contamination with different chemical decontaminants, (2) improved development of personnel exposure and contamination procedures, and (3) increased understanding of the waste handling methods required. 
5.2 Auxiliary Building and Fuel Handling Buildings

Decontamination of the surfaces within the Auxiliary and Fuel Handling Buildings was initiated shortly after the accident to allow normal operation of the necessary equipment within the buildings and to allow modifications to proceed on certain equipment. Currently, decontamition efforts in these facilities are progressing satisfactorily, and decontamination of all open areas (corridors, stairwells, etc.). is $80 \%$ complete. Equipment cubicle decontamination is $60 \%$ complete.

Initial conditions within the Auxiliary Building (refer to Fig. 16) are presented in Table 7.

Table 7. Initial condition of Auxiliary Building ${ }^{13}$

\begin{tabular}{cccc}
\hline $\begin{array}{c}\text { Elevation } \\
(\mathrm{ft})\end{array}$ & $\begin{array}{c}\text { Surface } \\
\text { contamination } \\
\left(\mathrm{dpm} / 100 \mathrm{~cm}^{2}\right)\end{array}$ & $\begin{array}{c}\text { Radiation } \\
\text { levels } \\
(\mathrm{R} / \mathrm{hr})\end{array}$ & $\begin{array}{c}\text { Airborne } \\
\text { I activity } \\
(\mu \mathrm{CH} / \mathrm{cC})\end{array}$ \\
\hline 281 & $1.5 \times 10^{7}$ & $>1$ & $6 \times 10^{-7}$ \\
305 & $7.0 \times 10^{5}$ & 0.08 & $2 \times 10^{-7}$ \\
328 & $4.0 \times 10^{3}$ & 0.01 & $1 \times 10^{-7}$ \\
\hline
\end{tabular}

As of September 7, 1979, all areas on the 328- and 305-ft levels of the Auxiliary Building were reading less than $5000 \mathrm{dpm} / 100 \mathrm{~cm}^{2}$ with the exception of six cubicle areas. The $281-\mathrm{ft}$ level was less than $10,000 \mathrm{dpm} / 100 \mathrm{~cm}^{2}$ except for six equipment cubicles. Two-thirds of the accessible areas in the Fuel Handling Building were reading less than $50,000 \mathrm{dpm} / 100 \mathrm{~cm}^{2}$. Radiation levels in the general background area are now less than $1 \mathrm{mR} / \mathrm{hr}$, except in the isolated tank areas and valve alleys. At present, no tank or internal piping decontamination has been accomplished. This effort will be scheduled when the details of water processing have been finalized.

The decontamination is being accomplished in accordance with an approved decontamination plan. In general, this $\mathrm{plan}^{14}$ describes a multistage effort that reduces contamination levels with a final goal of less than $1000 \mathrm{dpm} / 100 \mathrm{~cm}^{2}$ and reduction to normal design radiation levels. 
ORNL Dwg 79-15897R

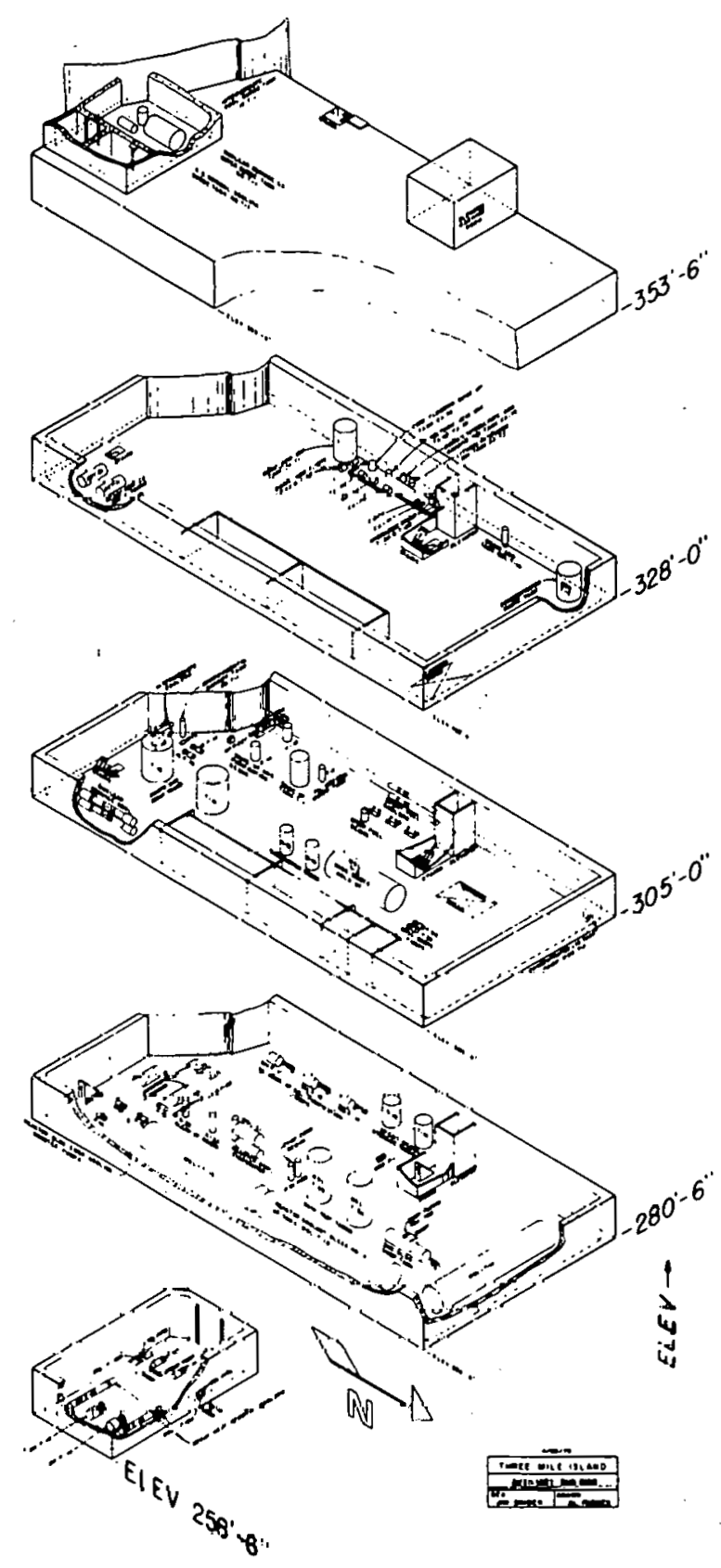

Fig. 16. Auxiliary Building layout. 
Some of the techniques and methods being employed in the decontamination program.include

1. application of various decontamination solutions (such as Radiac wash),

2. wet and dry vacuum methods,

3. muslin wipes,

4. strippable/protective coating application,

5. electropolish cleaning,

6. ultrasonic cleaning,

7. hydro-layer application, and

8. steam cleaning.

The decontamination effort is being supervised by experienced, qualified personnel. The work is performed by volunteer utility personnel from the GPU system. Prior to being assigned to a decontamination team, the utility personnel are required to participate in a decontamination and indoctrination training program. This program is primarily aimed toward the aspects of personnel safety, cross-contamination, and specific decontamination techniques.

\subsection{Containment Facility Recommissioning}

Basicaliy, the planning study ${ }^{1}$ for recommisstonilly the containment facility indicates that TMI-2 could be operational 42 months after initial reentry and after expenditure of about $\$ 250 \mathrm{million}$ to $300 \mathrm{million}$. The stepwise plan for this recommissioning is discussed below.

\subsubsection{Status of containment and components}

Current status has been interpolated from liquid samples, containment atmosphere samples, and direct radiation monitoring of the reactor coolant system (RCS). The three types of radiation/radioactivity sources are described as airborne, general plateout, and containment sump plateout.

A11 results indicate that extensive damage to the top of the fuel assemblies in the core occurred during the loss of water coolant when the fuel rods were exposed to excessively high temperatures. Significant fractions of the fuel (core) radioisotopic inventory were released to the 
primary (RCS) coolant and, therefore, to the containment sump. The noble gases and iodine were released to the gas phase, but the emergency sodium hydroxide $(\mathrm{NaOH})$ spray washed most of the iodine into the liquid phase.

Suggested effects from varying or unusual conditions have led to interpretation of component conditions. Localized temperature fluctuations have probably produced minimal effects; at most, some isolated damage may have occurred to some individual instruments, fittings, or seals. [Service conditions for the unit (during about 1 year of normal operations) were certainly nondamaging.] The hypothesized hydrngen hurning and/or explosion could have produced much more damaging, though localized, effects on the containment structure, RS.S, and components. Results or Lhis damage can only be ascertained when the facility is reentered.

The explosion (deduced from a pressure surge within the facility) triggered the basic $(\mathrm{NaOH})$ spray system; a potential consequence of the spray is corrosion, especially of carbon-steel components. Other unusual conditions include excessive radiation from the massive radioactive contamination in the containment facility (thus decreasing the effective remaining lifetime and reducing the reliability of equipment, containment coatings, organic seals, etc.) and flooding (the structure was unaffected but the equipment might show degradation, especially instrumentation and electrical components). The status of major cquipment is nuw being evaluated by B\&W (The Babcock \& Wilcox Co.).

The future status is dependent on the uncertainties of current equipment and structure conditions. In addition, decontamination procedures and materials will further affect equipment and components. One objective of the decontamination program is to minimize corrosion, which is expected to be more rapid for carbon-steel components. Corrosion is also apparently accelerated by partial (as opposed to complete) suhmersion, atmospheric humidity, and repeated ryc.les of wetting and drying.

\subsubsection{Major construction, services, and equipment requirements for}

The major envirnnmental requircment during the decontamination and reentry period is to prevent the spread of contamination. The most important sources of potentially hazardous radioactivity are airborne materials and transferable surface contamination. 
To prevent the spread of radioactive contamination, a Containment Service Building (CSB) will be built around the reactor equipment hatch as a contamination control envelope. There are four parts to the CSB: (1) a containment service area (a staging area for decontamination and equipment access), (2) a personnel access facility and change house, (3) a high-level radwaste staging area (for temporary storage of radwaste, especially high level, prior to shipment), and (4) a dry-cleaning facility (for decontamination or work clothing).

For support of remote and hands-on decontamination with containment, many services and much equipment must be installed for temporary use in the Containment Decontamination Service System (CDSS). The CDSS system includes the following:

1. equipment for remote decontamination spray and chemical addition (includes remote liquid and remote saturated-steam delivery equipment);

2. the Containment Ventilation and Filtration System (for control of pressure, temperature, and humidity within the containment atmosphere);

3. the Containment Temporary Lighting and Power System (for communications and control and monitoring containment);

4. the Containment and Service Building Breathing-Air System (to supply air for personnel entering contaminated areas);

5. a television system (for remote monitoring and recording of operations and for training of working personnel);

6. the Containment Vacuum System (for vacuum cleanup of solids and liquids);

7. a system for decontamination steam supply (to supply saturated steam for both nonspraying remote and local hands-on decontamination);

8. the Containment Chemical Supply System (for mixing and delivering chemicais to remote and hands on decontamination equipment);

9. the Containment Decontamination Water Supply and Recycle System (includes tanks for storage and supply, delivery equipment for remote and hands-on decontamination, and piping for recycle to and from the radwaste storage facility); 
10. provisions for equipment decontamination in the CSB loutside containment to prevent the spread of contamination and to collect and dispose of decontamination solutions);

11. the Containment Communications System;

12. the Containment Radiation and Radioactivity Monitoring Program (includes provisions for warning of potential criticality); and

13. the CSB Heating and Ventilation Systems (for the control of pressure and temperature in and the removal of airborne contamination from the CSB atmosphere).

\subsubsection{Containment reentry and decontamination}

Reduction of background radiation levels in the containment facility is required before personnel will be allowed to reenter. Initial removal of airborne radioactivity will be accomplished by atmospheric filtration and gas purge. Re-entrainment of airborne particulate duririy the decontamination program is inevitable, but constant vigilance and continuous. filtration of the CSB and containment atmospheres will minimize personnel exposure.

Initial remote water spray and flush cycles should remove much of the dissolvable plateout, especially from the containment sump. Even with efficient and effective remote decontamination, there will be hot spots under the steam generators, in the sump, and in puddles (because the floor is not perfectly flat). In addition, it has been assumed that up to $1 \%$ of the spent fuel was degraded and is now lying on top of the steam-generator tube sheets.

The five major phases of the containment decontamination effort are discussed below.

Remote containment decontamination. Since initial radiation surveys indicate lhat reentry of personnel would result in unacceptable radiation expusures, an effort to decontaminate the facility remotely before reentry may be initiated. The objectives of this effort are to reduce transferable contamination and to reduce the radiation fields within containment. Inherent goals include maximization of decontamination effectiveness and minimization of corrosive action, radwaste chemical processing, and radwaste volumes. 
Remote decontamination makes use of the containment spray system, which can contact about $60 \%$ of the exposed area. The liquids to be sprayed are deionized water, steam (allowed to condense on surfaces), detergent solutions, and chemical solutions. Chemicals will be used only as a last resort since they will be detrimental to the radwaste cleanup systems; some of the chemicals are also either flammable or too corrosive. The sprays are expected to dissolve or dislodge contamination and then to move it to the containment sump where the material will be flushed to the radwaste system. The decontamination factor is expected to be between 800 and 80,000 .

The last solution to be sprayed and flushed will be water that contains corrosion inhibitors. The solution will be allowed to flood the building to a depth of several feet. The solution will serve as a radiation shield against remaining plateout and hot spots. After the last spraying, the containment atmosphere will be conditioned to remove tritium $\left({ }^{3} \mathrm{H}\right)$ in liquid ${ }^{3} \mathrm{H}_{2} \mathrm{O}$ humidity form and to reduce the ambient temperature.

Containment atmosphere purge and filtration. The two major sources of airborne radioactivity are from the RCS; they are the gases (by the end of the year, they will primarily be ${ }^{85} \mathrm{Kr}$, a noble gas, and ${ }^{3} \mathrm{H}$ as hydrogen) and the suspended particulate (from initial core RCS release and from remote decontamination resuspension). The objectives of this effort are primarily directed toward minimizing the threat and impact on public health and safety and minimizing on-site operator/worker exposures. All releases (purges) of gas will comply with release technical specifications. Timely cleanup is required to minimize impact on the decontamination schedule.

Alternatives to the atmospheric purge were studied; the gas containing ${ }^{85} \mathrm{Kr}$ and ${ }^{3} \mathrm{H}$ could have been compressed and stored as a pressurized gas or treated cryogenically and stored as a very low-temperature liquid. In either case, an accidental release of most of the material could lead to an uncontrolled, hazardous situation. Gas purge can be readily controlled over entirely different meteorological conditions. Based on the maximum permissible concentration [found in the Code of Federal Regulations (10 CFR 50 , Appendix I)], the purge of the ${ }^{85} \mathrm{Kr}$ will take about 2 months. Tritium has a much higher permissible release rate associated with it; thus, ${ }^{85} \mathrm{Kr}$ is the controlling isotope for atmospheric release. 
The atmospheric cleanup, by filtration and purge, must be completed before personnel can reenter containment. The final filtration cycle prior to reentry will be run after remote decontamination has been completed.

Initial reentry. Two types of reentry have been proposed. If radiation levels are too high for initial reentry by personnel, a remotely controlled mechanical vehicle (robot) will reenter first. The robotic unit can be made available almost immediately upon demand. The robot would map $\beta-\gamma$ radiation fields extensively, carry a portable telev1sion for remote visual assessment of the containment, and take smear samples of the contamination. Later, the robot could be used for limited decontamination.

If the radiation levels are humanly tolerable, personnel will reenter containment. In addition to safe radiation exposure for workers, other criteria would also have to be met. Explosive gas mixtures (mainly hydrogen in air) would have to be absent, and air and sump sample analyses would have to show relatively low radioactivity levels. Avoiding both the spread of contamination to the CSB or another entry point and the release of airborne activity from containment are of primary concern. (The CSB will not necessarliy be complete; reentry could be made from the control room through another temporary contamination control envelope.)

General health physics plant procedures have already been established. Before personnel reenter containment, specific health physics decontamination procedures will have to be developed. The length of time personnel are allowed to remain inside containment is a direct. function of the radiation levels. The foremost objectives of personnel who reenter are (1) to develop a $\beta-\gamma$ radiation ficld survey, including average radiation levels and position and radiation levels of hot spots; (2) to visually assess the status of containment and the systems required to support it; (3) to take smear samples of contamination, including the hot spots. Other objectives, which will be conducted behind shielding and after further decontamination, will include (1) detailed radiation and contamination survey maps; (2) installation of television, lights, and radiation monitors; and (3) detailed containment and equipment damage assessments 
(for components, such as instrumentation and electrical power supply, and for structures, such as floors, vents, shielding, elevator shaft, etc.).

Hands-on decontamination. Health physics procedures will cover personnel support activities, protective clothing, and respiratory protection, as well as entry into and exit from containment, contamination control, personal equipment decontamination, and personnel exposures.

Gross decontamination will be accomplished at relatively long range (up to 50 feet), with fire-hose sprays of detergent solution (delivery of liquid through the Fire Protection System). Radioactive materials will have to be washed away quickly to minimize exposures. The largest problem facing work crews will be decontamination of the Containment Building Dome.

Detailed decontamination, from close range, will be accomplished with a wet, low-pressure steam spray containing detergent. Hot-spot decontamination will require scrubbing, surveying after each cycle, and fixing if removal is insufficient. Some materials (such as insulation, broken or damaged epoxy and plastic coatings, etc.) will have to be completely removed. Once areas and equipment have been decontaminated, they should be completely covered to prevent recontamination froil uther areas.

Most equipment will be partially or completely decontaminated with a flush and steam cycle. Equipment that is to be replaced will only be partially decontaminated to the point where it can be handled by personnel.

Temporary shielding will provide for reduction of personnel exposures; especially rrum hot spots or from equipment that cannot be cleaned.

Protection of essential equipment and systems. Equipment and systems may be essential for two reasons: (1) the need for continued safe shutdown of TMI-2 and (2) the requirement for containment decontamination.

Safe shutdown of TMI-2 requires the total integrity of the primary system for reactor-core heat removal. The steam generator(s) remove(s) heat by natural circulation in a water- or steam/watercooling mode. The decay heat from the reactor core is removed by naturally circulating reactor vessel water, which passes through the decay-heat-removal coolers. 
Crucial instrumentation is 1 isted as follows: the nuclear monitors, the steam-generator liquid-level and temperature indicators, the in-core thermocouples, the reactor-vessel pressure and temperature indicators, and the pressurizer temperature indicators. Instrumentation power supplies, connectors, and signal cables are essential. Pressurizer heaters, heater cables, and pressure-relief-valve power cables and connectors are critical. Motor-operated valves in the primary system are also needed. Mechanical equipment required include pressure boundary components, letdown and makeup systems, sampling systems, pressurizer pressure relief valves, insulation, RCS piping, the reactor vessel, the decay-heat-removal system, and containment piping and valves.

The containment elevator, cranes, lighting, air coolers, and electrical power system are considered essential to containment decontamination.

Protection for equipment and systems during remote decontamination will be provided by the proper selection and use of spray chemicals so as to minimize corrosion. The most significant effect will be equipment operability, especially in clcctrical components. The most sensitive items will be instruments, cables, and connectors. The halardous conditions to lir expected have already existed since the accident; therefore, the added effects from remote decontamination are expected to be minimal. A contingency $p l a n$ is needed in the event of failure of one or more major pieces of equipment or systems.

For hands-on decontamination, protection will be effected by administrative control through previously developed and approved procedures, which will be suited directly to individual component needs. Physical protection for items will be implemented.

Long-term wet layup for the steam generators and auxiliary support systems is being considered. The water will meet chemical requirements, and periodical chemical adjustments will be made. 


\subsubsection{Reactor coolant system cleanup}

There is very little definitive information available about the current RCS status. For purposes of this study, it has been assumed that the reactor pressure vessel, primary loop piping, reactor-coolant pump casings, steam generators, and pressurizer will not be replaced. In addition, it has been assumed that the nuclear steam supply system (NSSS) supports, bolts, studs, and embeds for major components will be reused.

Steps for the RCS cleanup are as follows:

1. removal of the reactor vessel head (likely to require shielding);

2. core inspection, which includes addition of special instrumentation, television cameras, and videotape systems;

3. removal of (spent) fuel; which will require special tooling, fuelpool modifications, and special procedures and equipment for shipment and disposal of the fuel (fuel and debris will be put into shipping cans and sent to a fuel processing facility or to a storage repository);

4. removal of the reactor vessel internals; and

5. decontamination of reactor vessel and its inlermals. The reactor vessel head will be replaced after cleaning the debris from the steam generators. The primary system will be chemically flushed. Any components or reactor internals will either be refurbished or replaced. Steam-generator tubes and tubesheets will be repaired, and RCS pump motọs will be rewound or discarded.

\subsubsection{Reconstruction and recommissioning}

The major underiying assumption is that there will be no political or legal problems associated with the analysis, safety assessment, and relicensing of TMI-2.

Major steps include procurement of tooling and inspection equipment, field inspection, testing, and reconstruction. Within the realm of reconstruction, the following activities will be accomplished: refurbishment and reinstallation of the RCS components, reinstallation of the containment 
air coolers and duct work, installation of electrical equipment (wire, cables, conduit, lighting, motors, penetrations, instrumentation, and communications), inspection and repair. or replacement of mechanical equipment, reinstallation of insulation, surface preparation and recoat of containment, and replacement of spent-fuel storage racks. Major equipment to be refurbished, or replaced if necessary, would include reactor coolant pumps and impellers, reactor internals, reactor pressure vessel head, control rods and drives, pressurizer safety and relief valves, incore instrumentation, and fuel handling machines.

Potential modifications would be included in the reconstruction. Recommissioning consists of field inspection., testing and analysis, safety assessment, and rel1censing.

\subsubsection{Wastes generated from decontamination}

The liquid wastes to be processed during the decontamination program come from the remote decontamination and reentry (up to 3 million gal), hands-on decontamination (approximately 1 million gal), and RCS cleanup (approximately 3 million gal). A total of up to 9 million gal of radioactive liquid waste may have to be processed and converted into solid waste for disposal.

Cleanup of the reactor fuel and debris will result in transuranic (TRU) high-level waste (HLW), which will have to be processed in order to recover unspent fuel value or permanently stored in a federally approved repository.

Solid waste will be produced from plastic sheeting, paper, clothing, mops, filters, masks and mask canisters, smears and samples, rags, tools, drums, air cylinders and tanks, carts, vacuum cleaners, lights, cables, piping, hoses, etc. Compactible waste will be packed into 55-gal drums. Uther waste will be packed into other drunls, size permitting. About $400,000 \mathrm{ft}^{3}$ of $\mathrm{dry}$, compacted waste is expected to be generated from decontamination and equipment discards.

\subsection{Costs and Schedules}

Based on previously discussed assumptions, the cost of TMI-2 cleanup is estimated to be: 15 


$$
\begin{aligned}
& \text { Subtota } \\
& \begin{array}{l}
\text { Contingency (33\%) } \\
\text { Total }
\end{array}
\end{aligned} \quad \begin{array}{r}
\$ 236,000,000 \\
79,000,000 \\
\$ 315,000,000
\end{array}
$$

A reasonable date for reentry of the containiment facility could be December 1979. Commercial operation of TMI-2 is projected to be 42 months after the time of containment reentry. The major assumption is that no political or legal problems will delay the schedule or add to the cost. This cost and schedule cover total refurbishment and return to service for TMI-2. 


\section{CONCLUSIONS}

\subsection{Contaminated Air}

Release of radioactivity to the environment as a result of the accident in TMI-2 was limited to the atmosphere. " The nobie gas release, primarily isotopes of xenon, totalled between 2.4 million and 13 million Ci. Only a very small fraction of the iodine in-core inventory was released to the atmosphere (13 to $16 \mathrm{Ci})$.

The successful retention of core-released iodine, dissolved in the reactur coolant (a limited amount in the Auxiliary Bulldirig water), is attributed to replacement of the charcual filter traps over the 2-week period from April 20 to May 3, addition of a supplemental off-gas filtration system, and capping of the exhaust stack.

\subsection{Contaminated Water}

\subsubsection{Low-activity-level water}

From Apri1 11 through June 6, 103,500 gal of slightly contaminated LALW was treated by the Epicor-I process. The treated water was subsequently released to the Susquehanna River.

\subsubsection{Intermediate-activity-level water}

There is approximately 279,000 gal of IALW currentiy in storage. Although secure in storage, the IALW represents a potentialiy mobile source of radioactivity; therefore, this water should be processed. Another advantage to be gained from processing the IALW is the resultant lower exposures to personnel who must work in the Unit 2 Auxiliary Bullding. Processing will be accomplished using the Epicor-II process.

Because NRC has evaluated the Epicor-II process and concluded that it will not affect the quality of the human environment, an Environmental Impact Statement need not be prepared. [Reference for this decision is 10 CFR $5 \overline{1} .5(\mathrm{c})$.

\subsubsection{High-activity-level water}

The HALW, from the primary coolant loop and reactor containment, requires special treatment because of its high radioactivity levels and

\footnotetext{
* Some radioactivity $\left(0.24 \mathrm{Ci}^{131} \mathrm{I}\right)$ was released to the Susquehanna River.
} 
excessive ionic content, especially borate and sodium. If the reactor system is to be recovered, the HALW must be processed. CNSI, with the aid of Allied-General Nuclear Services, has developed a process flowsheet that takes into account the unique nature of the fluid. Process tests, based on the actual HALW, were conducted in an ORNL hot cell.

\subsection{Radioactive Solid Waste}

Over the next 24 months, approximately 60,000 to $70,000 \mathrm{ft}^{3}$, of solid waste will be generated from the treatment of liquid wastes and decontamination of buildings (not including the Containment Building). A primary source of waste will be sorbents, both inorganic and organic, which remove the fission products from contaminated water.

A solid-waste staging area will be required as a buffer zone between waste generation on-site and waste shipment to burial site(s). A temporary interim storage facility is under construction, and a more permanent one is in the final stages of design.

\subsection{Facility Decontamination}

Since the exact nature of conditions within containment is unknown and no reentry has yet been attempted, the information contained in this report on the facility derontamination and recovery is not final and could change. Samples of contamination and radiation surveys have provided most of the available information. Valuable experience has been gained during decontamination of the Diesel Generator, Auxiliary, and Fuel Handling Buildings.

Reduction of the containment radiation levels is required before people will be allowed to reenter. Remote decontamination should reduce contamination and the resulting radiation field to the level whereby personnel can begin hands-on decontamination.

The containment atmosphere must be treated before initial reentry to remove tritium $\left({ }^{3} \mathrm{H}\right.$, probably in the form of ${ }^{3} \mathrm{H}_{2}$ and $\left.{ }^{3} \mathrm{H}_{2} \mathrm{O}^{*}\right)$ and ${ }^{85} \mathrm{Kr}$. The best method for control of this potentially hazardous concentration

* The normal molecular tritium-bearing compound will actually contain one atom of tritium and one atom of normal hydrogen; thus, the compounds will be $3_{H}-1_{H}$ and $3 \mathrm{H}-0-1_{H}$. This is due to the overwhelming majority of normal atoms $\left(1_{H}\right)$ over tritium atoms $(3 H)$. 
of radioactivity is filtration and controlled release to the atmosphere over about. a 2-month period. All releases will comply with release technical specifications (10 CFR 50, Appendix I).

Equipment and systems must be protected for continued safe shutdown of TMI-2 and containment decontamination. Protection wi11 be accomplished by proper selection and use of chemicals, administrative control through previously approved procedures, physical coverings, and long-term wet-layup for major components (such as the steam generators).

\subsection{Recommissioning}

The major underlyting assumption is that there will be no political or legal problems associated with refurbishment and relicensing TMI-2, and that no political or legal problems will delay the schedule or add to the cost.

A total of 9 million gal of radloactive 1 iquid waste may have to be processed and converted into solid waste for disposal. About 400,000 $\mathrm{ft}^{3}$ of dry, compacted waste is expected to be generated from decontamination and equipment discards.

Commercial operation of TMI-2 could resume as soon as 42 months after reentry. Cost is estimated to be between approximately $\$ 250$ million to $\$ 300$ million. 


\section{REFERENCES}

1. Bechtel Power Corporation, Planning Study For Containment Entry. and Decontamination (July 2, 1979).

2. R. E. Brooksbank and L. J. King, Involvement of ORNL Chemical Technology Division in Contaminated Air and Water Handling at The Three Mile Island Nuclear Power Station, ORNL/TM-7044 (August 1979).

3. J. G. Herbein, Third Interim Report on The Three Mile Island Nuclear Station 2 (TMI-2) Accident, Metropolitan Edison Company, GQL-0924 (Ju1y 16, 1979).

4. J. T. Collins, W. D. Travers, and R. R. Bellamy, "Report on Preliminary Radioactive Airborne Release and Charcoal Efficiency Data: Three Mile Island Unit 2," presented at Moscow, U.S.S.R., June 1979.

5. Porter-Gertz Consultants, Effluent Releases From TMI Units 1 and 2 For First and Second Quarter (August 1979).

6. J. Auxier et al., President's Commission on The Accident at Three Mile Island - Report of The Task Group on Health Physics and Dosimetry (Aug. 31, 1979).

7. Nuclear Regulatory Commission, Environmental Assessment - Use of EPICOR-II at Three Mile Island, Unit 2, NUREG-0591 (Aug. 14, 1979).

8. R. R. Reust, CNSI-TMI Water Cleanup System Process Description, Draft No. 1 (Aug. 8, 1979).

9. B. Rusche, "Status of TMI," Institute For Energy Analysis, Aug. 23, 1979 (unpublished draft).

10. R. E. Brooksbank, "Contaminated Air and Water Handling," presented to the Prcsident's Cominission on the Accident at Three Mile Island, June 12, 1979.

11. B. Rusche, personal communication to R. E. Brooksbank, Aug. 14, 1979.

12. A. A. Buchalz, letter to R. E. Brooksbank, dated Aug. 23, 1979; subject: "Transportation Equipment Availability for Shipment of Radioactive Waste."

13. J. A. Renshaw, personal communtcation to R. E. Brooksbank, Sept. 7, 1979.

14. J. F. Remark, W. A. Shannon, and A. D. Miller, "Plan for Decontamination of the Auxiliary and Fuel Handling Buildings," June 15, 1979 (unpublished report). 
15. Bechtel Power Corporation, Prel iminary Assessment of Potential cost and Schedule (July 2, 1979). 
ORNL/TM-7081

INTERNAL DISTRIBUTION

1-3. W. J. Armento

4. J. E. Bigelow

5-27. R. E. Brooksbank

28. D. 0. Campbell

29. E. D. Collins

30. D. E. Ferguson

31. F. E. Harrington

32. L. J. King

33. F. R. Mynatt

34. J. R. Parrott, Sr.

35. H. Postma

36. W. A. Shannon
37. J. W. Snider

38. D. B. Trauger

39. R. G. Wymer

40. 0. 0. Yarbro

41-42. Central Research Library

43-44. Laboratory Records

45. Laboratory Records, RC

46. ORNL $-Y-12$ Technical Library Document Reference Section

47. ORNL Patent Section

48. Engineering Physics Information Centers (EPIC)

\section{EXTERNAL DISTRIBUTION}

49-73. Office of the Assistant Manager, Energy Research and Development, DOE-ORO, P. O. Box E, Oak Ridge, TN 37830

74-100. Technical Information Center, Oak Ridge, TN 37830

101-116. Dr. W. R. Stratton, President's Commission on the Accident at Three Mile Island, 2100 M Street, NW, Washington, DC 20037

117-121. Dr. Bruce Mann, Nuclear Engineering Department, University of California, Berkeley, CA 94720 